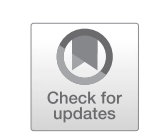

\title{
The Third Wave: The International Financial Crisis and Refugees
}

When the International Financial Crisis of 2008 was chewing into people's livelihoods, distaste for the political establishment had already been building for decades. In its wake, nativist populism rose to new heights, now also spreading far into the mainstream. This was illustrated in wide calls for leadership renewal. In fact, political experience was generally being dismissed, with increased appetite instead for inexperienced newcomers.

This was the time of the political novice. In other words, it was the amateurization of political life in the West. Even in firmly rooted democracies, traditional politics were giving way to populists. The third wave of nativist populism also brought a transformation in their appearance. These were no longer rogue demagogues revelling in Nazi symbolism, as in previous eras. Instead, populist leaders now looked like normal politicians.

As I will illustrate in this chapter, the third wave saw the spread of populist nationalism further into the mainstream in European and American politics than ever before. The new wave brought Brexit to the UK, Donald Trump to power in America and Marine Le Pen qualifying to the second round in the presidential elections in France, where she bagged a third of the vote. Indeed, this was a brand-new world. It is telling for their reach that the four largest democracies in the world-Brazil, Indonesia and India in addition to the US-were all governed by politicians often labelled as being populist.

In Europe, populists came into government in Austria, Greece, Finland, Hungary, Norway, Poland and Switzerland. In Italy, two populist parties,

(C) The Author(s) 2020

E. Bergmann, Neo-Nationalism, https://doi.org/10.1007/978-3-030-41773-4_5 
the Five Star movement and the quasi-fascist Lega, united in government. Even in Germany, far-right populists were also surging.

The president of the Generation Identitaire, Arnaud Delrieux, described this change as the age of identities, for it is the very essence of the European people that is threatened by the steamroller of globalism, the immigration invasion and multiculturalism' (qtd in Zúquete 2018).

In the third wave, nativist populism had grown far beyond Cas Mudde's (2004) coining of the phrase populist zeitgeist. Populist discourse was moved out from the fringe and into the mainstream - even fully adopted by government parties in some instances. Whichever way we dissect this trend, the third wave brought a fundamental shift in the evolution of nativist populism and came to constitute a clear trend of Neo-Nationalism spreading across Europe, America and elsewhere.

The third wave was fuelled by two main consecutive events hitting the Western world, first the International Financial Crisis culminating in 2008, followed by the Refugee Crisis heightening in 2015. Nationalist sentiments were again heightening with the Coronavirus Crisis of 2020.

\section{The Credit Crunch}

The International Financial Crisis brought the extraordinary economic boom of the early noughties to a stark halt. Indeed, this was the most serious economic calamity since the inter-war Great Depression. The troubles arose around sub-market housing mortgages in the US in 2007, turning into a full-blown Credit Crunch in the following year. The crisis shook the foundations of Western capitalism, bringing economic uncertainty, severe public austerity and increased hardship on the ordinary public, which largely felt victimized by both business and political elites.

The fall of Lehman Brothers on 15 September 2008 was a watershed moment, turning troubles into a serious banking crisis. In October Iceland, the small island country in the northwest Atlantic, became the poster-child of the global Credit Crunch when all of its oversized international banks came tumbling down within a single week, amounting to one of the world's greatest national financial crises (Bergmann 2014b). This was a financial tsunami without precedent in contemporary times. The crunch also illustrated a vulnerability in the internationalized economy of the West.

In 2009 the crisis was contesting the very fabric of the European economic system and was posing an existential threat to the Euro, the shared currency of many EU member states. Leaders on the continent responded 
to the crisis with imposing severe austerity measures onto vulnerable countries that were most seriously affected by the malaise. In effect, leaders in Berlin and Paris and other powerful players within the EU were able to coerce authorities in Athens, Rome, Lisbon, Madrid and in other economically weaker EU capitals to accept grave financial burdens in exchange for direly needed bailout, in order to save their countries from defaultswhich in turn was threatening to turn into a domino-effect of bankruptcies around the continent.

The austerity measures spurred mass protests among the affected public. With it, the political establishment was largely losing credibility in the eyes of the burdened people, leading to nationalist and populist actors gaining ground in many European countries. On the left flank, populists were gaining ground in Greece and Spain. However, populists were surging more on the right, leading to a paradigm shift in increased support for rogue challengers to the mainstream liberal democratic order.

\section{The Rise of the Third Wave}

As I will document in this chapter, the third wave saw nativist populism firmly moving from the fringes to become normalized. Most of these parties had abandoned open xenophobia, rather dressing their messages within more acceptable rhetoric. In the UK for instance, the more toned down populist UK Independence Party was replacing the openly racist BNP, which I discussed in the previous chapter. Later, the Brexit Party took over the rollers for a while. In France, the National Rally (previously named the National Front) found renewed support under the leadership of the more composed-looking Marine Le Pen, who had replaced her more aggressive father Jean-Marie Le Pen.

One of the greatest successes of populist parties in the third wave came in the 2014 European Parliament elections. In Denmark, France and the UK populists surged to the very front. Five years later, populists entered the EP in even greater numbers. Prior to the 2019 elections, European far-right populists had attempted to forge a continental alliance under the leadership of Italy's Matteo Salvini and Marine Le Pen in France. The US far-right strategist Steve Bannon was also trying to unite European populists in his Brussels-based group called The Movement. Bannon described Brussels as the beating heart of the globalist project, and said he wanted to 'drive the stake through the vampire' until the whole system started to disintegrate (qtd in Lewis 2018). 
However, as I discussed in the Introduction to this book, it has proven difficult to unite nationalists across borders in a meaningful way, as each is primarily focused on domestic aspects. These parties have thus found difficulties in co-operating in the European Parliament and have, more or less, been split into at least three separate parliamentary groups. One of their dividing issues was that of Russia. While Salvini, Le Pen and Orbán aligned with Vladimir Putin, especially due to his opposition to both the US and the EU, others were more wary of Russia, for instance the Scandinavians and those in the Baltics, as well as also Kaczynski of Law and Justice in Poland.

Euroscepticism was also finding its way to Germany with the rise of Alternative for Germany, which secured significant support in the 2017 parliamentary elections. In the third wave, such sentiments were indeed spreading much further even in many of the more traditionally pro-EU countries than they had done in the two previous waves.

Populism was also on the rise in South America. The Chávismo regime in Venezuela had consolidated power, incarcerated leading opposition figures, and firmly forced much of media and civil society under their will. In 2017, Chávez's successor, Nicolás Maduro, dissolved parliament and shifted authority over to the newly established Constituent Assembly, which adhered to the will of the Chávismo regime.

Over in Greece, different kinds of populists were competing for power. Landing more than a fourth of the vote in 2012, the left-wing populist Syriza was sweeping across the country. When coming into government three years later they for example had to rely on ANEL, a small xenophobic right-wing party. That was necessary for keeping the neo-Nazi, Golden Dawn, from power. Over the course of the Euro Crisis Syriza became more and more domesticated, gradually adhering to demands from EU creditors of implementing austerity.

Left-wing populists also rose up in Spain, where anti-austerity Podemos was contesting traditional politics, taking more than one-fifth of the vote in the 2015 election. The mainstream Popular Party, which had been formed in the wake of Franco's death, was already highly nationalist. Nationalism in Spain also had a secessionist side, most notably in Catalonia and in the Basque country. Rough far-right movements had long found difficulty in breaking through, perhaps because of Spain's relatively recent fascist history. However, in the second general election of 2019, far-right populist Vox party came in third place, winning 15 per cent of the vote, and landing fifty-two out of 350 seats in parliament. 
This was also a period of many contradictions. While most of the nativist populist parties were in this period getting rid of their openly xenophobic symbolism, this era also saw several more militant and openly racist parties gaining support in many other European countries. In Bulgaria the Attack Party was growing and the Jobbik movement in Hungary was at the time still outright neo-Nazi.

With many of these parties finding increased acceptability in society, even discredited authoritarian leaders of the past were again being rhetorically resurrected. Jörg Haider of Austria, for instance, dismissed much of the discussion around Austria's Nazi past, and leader of the Italian Lega, Matteo Salvini, openly voiced his admiration of Mussolini. In Russia, Vladimir Putin repeatedly moved to resurrect Stalin's reputation. Notorious policies that for a long while were collectively dismissed - such as of religious and racial segregation-were also emerging to the surface again.

Most horrendous in this third wave were several violent acts committed by far-right extremists. Amongst these were the attacks by Norwegian terrorist Anders Behring Breivik in 2011, and Tomas Mair who murdered MP Jo Cox in the UK in 2016. In 2019, Muslims were targeted by a shooter in Christchurch in New Zealand, and another shooter turned on Latinos in the US border town of El Paso. All of these perpetrators were believers in the extremist-right conspiracy theory called The Great Replacement. This is the belief that Muslims or other groups of migrants are actively plotting in secret to conquer the West in a hostile, albeit incremental, takeover.

Instrumental for the rise of nativist populism in the third wave was also the simultaneous growth of social media, which provided for much faster distribution of both fake news and controversial populist views.

\section{Social Media and Fake News}

The proliferation of fake news and conspiracy theories coincided with the emergence of digital media. Spreading lies and fabricated news stories to demonize political opponent is of course nothing new. In fact, it is right out of Machiavelli's (1550) playbook. Rumours, urban legends, folklore and other kinds of oral transmissions have always existed in human societies. And fabricated news was also spread by mainstream media outlets in the twentieth century. Distribution of bogus tales is thus not in itself a novel act. However, the emergence of the 24-hour rolling news broadcasts proved to be especially fertile for conspiratorial populists in transmitting distorted information. The take-off for these tales then became 
exponentially faster with the rapid growth of first online and then the social media outlets that followed. Since 2016, conspiracy theories, disguised as news, were blazing like a snowstorm across the political scene on both sides of the Atlantic.

British journalist and broadcaster Francis Wheen (2005), argued that reason was on the retreat in contemporary political discourse. Instead, he wrote that 'cults, quacks, gurus, irrational panics, moral confusion and an epidemic of mumbo-jumbo' characterizes our era. He warned that the values of the Enlightenment - the insistence on intellectual autonomy, commitment to free inquiry and dismissal of bigotry and persecutionwere fast being abandoned.

The research by communications scholars in both Europe and in the US reveal that social media is the primary source of news for most people of the younger generations (Krasodomski-Jones 2019). This is a fundamental shift in the way we learn about the world and how we come to foster opinions. The revolutionary change in the media mechanism which the world rushed through in less than two decades has served to enable conspiratorial populists to bypass the previously powerful gatekeepers of the mainstream media, and instead bring their combative and polarizing political messages directly to the public. As a result, people have become exposed to much more unscrutinized information than ever before.

This overflow of information can render the public incapable of properly interpreting the avalanche of data that they are being exposed to. In effect, too much information can result in preventing us from being able to absorb knowledge in a meaningful way. In this flood of indiscriminate information people can find difficulty in navigating between facts and fabrications. When everything is true, nothing is true. This has opened up a space for misinformation to thrive, leaving the democratic space highly vulnerable to manipulation. Indeed, this has led to the emergence of a new political culture emerging, which has been branded Post-Truth politics.

Distorted information has impacted political discussion to the extent that debates in democratic elections have increasingly come to revolve round false stories. This has also facilitated the increased use of all kinds of informal rhetorical fallacies, which were discussed in a previous chapter. In this change, which has brought contradictions being openly embraced, a discourse appealing to emotions has grown stronger, with diminished emphasis on factual reasoning. This has resulted in public debates becoming more easily disconnected from testable facts. In this climate, discredited knowledge can smoothly rise to an equal prominence with established knowledge. 
In both the Brexit referendum debate, and leading up to the US 2016 presidential election, data analysis company Cambridge Analytica was accused of manipulating social media by mining people's online data in order to produce individually targeted messages addressing different fears people were identified as bearing. Voters were bombarded with separate and sometimes contradictory content which was only loosely connected to reality, if at all. Here, we have entered into an era of information warfare, where people's private data has been weaponized and, indeed, often turned against the owner.

As I will discuss throughout in this chapter, conspiratorial populists have within this relatively new climate proved to be especially successful in spreading suspicion of the mainstream media, and against established knowledge which they claimed was produced by the elite, and eschewed in favour of the powerful. Alongside diminished gatekeeping capabilities of the mainstream media it becomes ever more difficult for people to distinguish between factual stories and fictitious news often spread via unscrupulous websites, as both can be presented in the same guise. And as Karen Douglas and her collaborators documented (2017), once a false story of a conspiracy takes hold, it can prove difficult to uproot.

This glut of fabricated information has also infiltrated more traditional media, which often picks up fabricated news and reports it as facts. Jovan Byford (2011) documents how CNN in the US broadcasted the agenda of the so-called Birther movement-the claim that former President Barack Obama was born in Kenya and therefore never eligible to be US President. Some insisted that he secretly was, in fact, a Muslim. Conspiracy theories were blazing during the Coronavirus Crisis of 2020.

The contagions of fake news, which initially were only spread from unscrupulous outlets is completed when it infects the mainstream media which duly distributes the fabricated stories, citing the bogus tales as a credible source. Here the mainstream media is turned on its head to become a far more powerful vehicle for fake news than social media outlets were ever able to do on their own. Only when picked up by the mainstream media does the distorted data find full credibility.

\section{The Spread of Conspiracy Theories}

In this new media environment, conspiracy theories have spread more easily than before.

Among the most persistent far-right conspiracy theories are suspicions of a New World Order dominating the world. Tales of the phenomenon 
have been prevalent over the last two centuries. Most often they revolve around global elites manipulating national governments. Commonly these bands of concealed evildoers are also accused of controlling international organizations behind the scenes, such as the International Monetary Fund, the United Nations and the World Bank.

The European Union is perhaps the international actor most often suspected of being this kind of a New World Order. Hungarian writer Janos Drabik (2017) for instance claimed that the EU is the institute of the plutocratic world-elite'. He insisted that the EU was not constructed for the benefit of the European people, but by the world-ruling elite. 'It is the transnational monetary cartel holding power over states that wants to get rid of national states by all means.' Drabik wrote that the global system was 'controlled from one single centre' and moved on to insist that the 'worldruling elite has gradually annihilated the achievements of the Enlightenment'.

The EU has indeed for long been a target of many conspiracy theorists. Well-paid EU functionaries are popular culprits in many tales of a malignant order of this sort. Some say that the EU is the Roman Empire resurrected, others have claimed that it is a super-state led by the Antichrist. There are even those insisting that the institution itself is the Antichrist. In one version, it took the formation of a computer hiding deep within the Brussels apparatus, keeping track of everyone in the world (Boyer 1995).

A younger and perhaps also a more modest relative of New World Order theories are those of a Deep State controlling countries behind the scenes. In these, a domestic band of clandestine elites is suspected of ruling nations or regions. In these stories, society is seen not to be ruled by its official authorities, but instead by a secret band of hidden actors, a covert bureaucratic class. In Turkey, the term derin devlet refers to a cartel of politicians and bureaucrats in different governmental branches together with high-ranking military officials, as well as organized crime, covertly controlling the country.

Clearly, these kinds of suspicions might have some merits. Power can easily lie with people we do not know of. But when relentlessly upheld by populist politicians without evidence, they come to erode trust in society. And when these once peripheral politicians gain support and acceptance, and indeed power, then conspiracy theories become competitive knowledge.

Deep State theories rose to renewed prominence around the Tea Party in America. They were then elevated to new heights in the presidential campaign in 2016, which brought Donald Trump to power. In this latest version, a clandestine elite within the state apparatus is accused of 
manipulating American politics and government in a co-ordinated and systematic manner. Most proponents of this theory point to bureaucracies of the military complex and to spy agencies. Among them was the president himself. Donald Trump for instance described the Deep State as 'real, illegal and a threat to national security' (qtd in Porter 2017). In a 2017 poll, $A B C$ News and The Washington Post found that almost half of Americans believed in a conspiratorial Deep State in the US.

During the Coronavirus Crisis of 2020 a range of conspiracy theories were spreading around the world. One, which was, for example, promoted by Republican Party Senator Tom Cotton, insisted that the virus had been created in a weapons lab in China to undermine Donald Trump. Trump's campaign advisor, Roger Stone, was amongst those that suspected that Bill Gates might have been involved in creating the virus in order to plant microchips in people (Fredricks 2020). A Pew Research Centre study in April 2020 found that $29 \%$ of Americans believed that Covid-19 was made in a lab (Schaeffer 2020).

\section{The Great Replacement Theory}

Another category focuses on external threats that can either be posed from aggressive foreign actors or infiltrators. As I have already mentioned, the most prominent theory around dangerous outsiders in contemporary time is that of Muslims occupying Europe and America-the fear of Muslims replacing the Christian population with Islamists. These have included notions of a White Genocide and the Eurabia theory.

In 2011 a deeply controversial French philosopher, Renaud Camus, titled his book as The Great Replacement. He argued that European civilization and identity was at risk of being subsumed by mass migration, especially from Muslim-dominated countries, and because of low birth rates among the native French people. Camus became one the most influential thinkers of the French Identitarian movement, which I discussed previously. This movement has grown fast among nativist populists, rooting in countries like Austria, Denmark, Germany, Italy and the UK.

Numerous nativist populist leaders in Europe have since promoted this theory, for example by nurturing the myth that migrants-especially Muslims - were taking over our national soil and heritage. This fear was nurtured by Geert Wilders of the Freedom Party in the Netherlands, who said that immigration was the greatest threat facing European culture. Wilders said that if Europe failed to defend itself against these malignant forces, it would be because Europe no longer believes in the superiority of 
its own civilization. On Twitter Wilders (2017) wrote: 'Our population is being replaced. No more.' Wilders linked his words to a video clip showing Muslims dominating the streets in Amsterdam. The video was titled 'Is this Iran or Pakistan? No, this is Amsterdam, the Netherlands.'

After pointing to this external threat to the nation, Wilders-in a classic Neo-Nationalist move-turned to accusing the domestic elite: 'In the Netherlands we are dealing with a social elite who are undertaking what I call an attack on the nation state, who undermine the Netherlands, who are hostile to the Dutch identity-hence multiculturalism, open borders, the European Union' (qtd in Duyvendak and Kesic 2018).

This is but one example of many similar moves made by several NeoNationalist leaders in Europe indicating that Europe was facing a hostile Muslim takeover. In Austria, H. C. Strache wrote that the Great Replacement had already taken place under mainstream governments. In Belgium, Dries Van Langenhove of the Flemish Block (VB) said 'we are being replaced' (qtd in Davey and Ebner 2019). In the 2019 federal elections, the VB had regained its former strength and again landed almost 12 per cent of the overall vote, becoming the second largest party nation-wide.

As will become evident in this chapter, the Great Replacement theory rose to new heights in the third wave of nativist populism. Sometimes proponents of the story have alluded to the full conspiracy theory, of malignant domestic forces orchestrating a population change in a campaign of ethnic cleansing aimed against the Christian white population.

An extensive quantitative study measuring the spread of the theory found that between April 2012 and April 2019 one and a half million tweets referred to the Great Replacement theory (Davey and Ebner 2019). The volume steadily grew over the period. The theory has also been fast moving into the mainstream. Both the mainstream media and traditional political parties started to follow suit.

Before the 2017 general election in the Netherlands, the centre-right Prime Minister Mark Rutte took out advertisements in several national newspapers where he criticized immigrants who refused to align with Dutch society. One of them read: 'Act normal or go away.' The aim was obviously not solely to convince Muslims in the Netherlands to change their ways. Rather the purpose was to reassure voters that they could trust Rutte to stand firm on migration, and that there was, thus, no need of supporting Wilders in order to take a tough stand on immigrants (Fekete 2018). 


\section{SHARIA PANIC}

The Great Replacement theory was also alive and well in America. Senior editor at the Atlantic magazine, Adam Serwer (2011), identified a conspiracy theory he called the Sharia panic. This is the fear of American Muslims trying to undermine the US constitution and planning to overthrow the government. This was evident in the chants of neo-racist protestors in Charlottesville in Virginia in 2017, as I will discuss later in this chapter. Another and more specific version insisted that Muslim terrorists were hiding in about twenty-two to thirty-five secret training camps around America (see in Potok and Terry 2015). As I will also discuss later in this chapter, Latin American immigrants have also increasingly been portrayed as foreign invaders and as posing a threat to the demographic composition of the US.

Among those buying into this Great Replacement theory were several violent actors, such as the Australian terrorist in New Zealand who on 15 March 2019 killed fifty-one people in Mosque shootings in Christchurch. A seventy-four page so-called manifesto published by the shooter was simply titled The Great Replacement. It followed all the tropes of the White Genocide conspiracy theory and pointed to classical antagonism between the Christian and the Muslim world, and indeed alluded to a global war between the two.

The twenty-eight-year old attacker referred heavily to the French Identitarian movement, and he had donated significant amount of money to them (Davey and Ebner 2019). He also hailed Donald Trump as 'a symbol of renewed white identity and common purpose'. The shooter furthermore revealed that prior to the attack he had gotten the blessing of the notorious Norwegian terrorist Anders Bhering Breivik. Writing in the Guardian, Jason Wilson (2019) notes that the Christchurch shooter was brought up in Australia in a period when racism, xenophobia and antiMuslim hostility had been normalized.

Tellingly for the times, the notorious act was livestreamed on Facebook and shared with millions of people. Australian senator for Queensland, Fraser Anning, wrote in the aftermath of the attack that the violence was the fault of migration and Muslims. 'The truth is', he wrote, 'that Islam is not like any other faith. It is the religious equivalent of fascism.'

As previously mentioned, these same notions were also upheld by the murderer of Jo Cox in the UK, and the Norwegian terrorist Anders Behring Breivik, who believed that the Labour Party in Norway was in on 
the plot with the Islamists. I will return to discussing these violent responses to the Great Replacement theory where appropriate later in the text.

Conspiracy theories around Muslims have indeed been abundant in the milieu of the Neo-Nationalists. One insisted that a Muslim caliphate created the horrendous 2014 Ebola epidemic in Western Africa, and planned to weaponize the virus, for example by blowing up an Ebola victim on the busy Times Square in New York City. Perhaps the most far-fetched claim is that Islamic fascists inhabit the centre of the moon.

The progression of these tales in society is indicative of the snowballing effect of populism. Given the right conditions and texture they can trundle like an uncontrollable avalanche down a hill.

\section{The Syrian War and the Refugee Crisis}

The Great Replacement theory was elevated to new heights with the Refugee Crisis peaking in 2015 and 2016. In the wake of the conflicts in Syria and other countries in the Middle East and North Africa, Europe met with a sudden increased influx of refugees from Muslim-dominated countries. This brought renewed tensions over migration and counts as a significant shift within the third wave of nativist populism.

In fusing the frustrations of the Financial Crisis which was burdening the ordinary man, with fear of mass Muslim migration from war-ridden countries in the Middle East, nativist populism was growing to new levels. Underlying these fears was also the ongoing threat of Muslim terrorismin less than a decade more than dozen major terrorist attacks had been committed by Muslim actors in Europe.

With the increased flow of migrants from Muslim-dominated countries, right-wing populists in Europe have firmly moved away from their anti-Semitic stance of former times. Instead they have come to focus on a covert Islamist plot of taking over control in Europe. This is one of the distinctions between the fascist version of nationalism in the interwar years and the nativist populist Neo-Nationalism of the post-war years.

Although we have surely seen a significant evolution in the demographic composition of Europe since the Second World War, with increasing numbers of people coming from the Middle East and North Africa, the sudden flood of refugees out of Syria in 2015 did not alter the demographic construction on the European continent in any drastic way. Still, that is exactly what many nativist populists have maintained. In wake of 
the crisis, which receded in 2017 and 2018, Muslims accounted for only roughly 5 per cent of the population in the European Union. An estimation by the Pew Research Centre indicates that by the year 2050 the Muslim population will rise to between 7.4 and 14 per cent. ${ }^{2}$ Many of these people are, however, expected to move away from their traditional Muslim heritage and integrate into the contemporary European lifestyle.

Studies have found that people tended to overestimate the Muslim population. In France, respondents in the before-mentioned study thought that Muslims stood at 31 per cent, when in reality they were 8 per cent. In America, respondents on average thought that Muslims amounted to 17 per cent of the population, when in reality they were only around 1 per cent (ibid.).

Despite the relatively low percentages of immigrants in the Westcompared to the intensity of the public debate about them-fears of immigration were still dominating much of politics in Europe. A poll in 2016 found that around two-thirds of respondents in countries like Denmark, Hungary and Germany said that immigration was the most pressing political issue at the time (Mounk 2018). Correspondingly, a UK study found that immigration was the most common concern directing a Leave vote in the Brexit referendum (Judis 2018).

Given this distortion between perception and reality it is perhaps not surprising that immigration was often found to be the most pressing political issue, only surpassed by fear of terrorism.

\section{Alternative for Germany}

Germany is an especially interesting case for analysing the third wave of nativist populism. Mainly due to the desolations of the Nazi past, nationalism had in the post-war era been discredited and indeed firmly suppressed in Western Germany. However, during the Euro Crisis, and the following Refugee Crisis, nationalism was also re-emerging in Germany. Over the past two decades Germany had in a way sublimated its nationalism into the European Union. In other words, its pro-EU position can be seen as a kind of cloak for national ambitions on the world stage.

Similar to the True Finns in Finland, the party Alternative for Germany (Alternative für Deutschland-AfD) was established in 2013 in opposition to bailing out mainly southern European countries during the Euro Crisis. Due to several academics present in its leadership they were initially and ever so cosily branded as the Professors' party. Soon though, they 
broadened their appeal. The influential tabloid Bild also threw its weight behind that same message. One of its many headlines on the subject read: 'Stop! No More Billions for the Greedy Greeks' (qtd in Barfield 2015).

With the Refugee Crisis rising to new heights, another movement was also gaining more ground: Patriotic Europeans against the Islamization of the Occident (PEDIGA) took to organizing many protest rallies against Muslims and migrants around the country, mainly in the former eastern part. Among their slogans was 'Wir sind das Volk', meaning 'we are the people'.

The Refugee Crisis of 2015 marked a turnaround for populist politics in Germany. At its height, Chancellor Angela Merkel reversed her policy of stemming the tight of refugees and decided to allow Syrian mass migration into Germany. 'We can manage this', she famously declared. Within a year more than one million refugees were allowed entry into Germany.

This was a reversal of her previous opposition to immigration. Previously she had catered to the concerns that many nationalist conservatives had over immigration. At a conference of the party's youth movement in Potsdam in 2010 she declared that multicultural society had 'utterly failed', maintaining that the idea of different cultures living happily side by side 'did not work' (qtd in Fekete 2018).

With her decision in 2015, Angela Merkel then became the (unlikely) spearhead of the multilateralist and liberal democratic Europe. The leader of the conservative Christian Democrats - an east-German daughter of a protestant pastor, and a staunch believer in transatlantic relations-was now being celebrated by the social liberal left in Europe. For the brave decision, Time magazine in America crowned her Person of the Year.

Not all were happy though. She instantly came under massive criticism from conservatives and nationalists. After several criminal incidents committed by migrants in Germany, nationalist and anti-Muslim voices grew louder. After the 2015/16 New Year's Eve festivities in Cologne, news stories were breaking of mass mobs of migrants sexually harassing and even raping native German women. This spurred an outrage across the country and seriously undermined Merkel's open-door policy. Nicole Hörchst, AfD Member of Parliament, used the opportunity to place her nativist populist party as the only protector of women's rights in Germany, pointing to the 'danger of losing the freedoms and rights of women for which we've fought for centuries' (qtd in Chrisafis et al. 2019).

When the stories of harassment were later rolled back as blown out of all proportion, and indeed for being mostly false, many within the nativist 
populist milieu dismissed the correction as coming from the lying press, Lügenpresse in German (Fekete 2018.).

\section{The New Nationalists}

To understand the sudden rise of nativist populists in Germany, like elsewhere in the third wave, it is necessary to examine the conjunction of these two otherwise separate crises, the Refugee Crisis following the Euro Crisis. These two trends gradually found a unified platform within the AfD. For the first time since the Second World War, prominent forces in Germany were defying the defamation of nationalism in Germany. Underground far-right nationalist movements had of course, always existed in the post-war era. In 2011, a neo-Nazi terror cell called the Nationalist Socialist Underground was revealed as having over previous decades committed several murders and other violent acts, against mainly Muslim migrants (Fekete 2018). By 2017, however, nationalism was no longer only underground in Germany.

With the Refugee Crisis, AfD representatives were no longer primarily focused on rolling back European integration and stopping financial aid to crisis-ridden countries. Under Frauke Perry, the party firmly set its sights against migration, rejected the ideals of multiculturalism and declared that 'Islam does not belong in Germany' (qtd in Judis 2018). Party leaders have said that people of non-German ethnic origin cannot be considered as belonging to the German nation. Perry also wanted to widen the appeal. Similar to attempts made by the Sweden Democrats-discussed later in this chapter-she wanted the AfD to fill the vacuum left by the German Social Democratic Party.

AfD representatives have also questioned taboos around the country's Nazi past, suggesting that Germans should be allowed to be proud of their military actions in the past. Björn Höcke for example questioned the relevance of the Holocaust monument in Berlin, saying that Germans 'were the only people in the world to plant a monument of shame in the heart of their capital' (qtd in Judis 2018).

In the 2017 election, Alternative for Germany won 12.6 per cent of the vote and became the third largest party. This was the first time a far-right nationalist party got elected to the German parliament since the Nazi party in 1933. The rise of the AfD is perhaps one of the most significant indicators of how far into the mainstream Neo-Nationalism has travelled in the third wave. Echoing the rhetoric of Trump in America, and that of 
the Brexit campaign in Britain, AfD leader Alexander Gauland set out 'to take our country back' (qtd in Snyder 2018). The two main parties responded with again forming a grand coalition across the political spectrum, leading the AfD to become the country's primary opposition party.

Since the Refugee Crisis of 2015 the AfD has been promoting the Great Replacement conspiracy theory, discussed above. Migrants were placed as the external threat to Germany, while mainly the Western German political elite were cast as the domestic traitors. Before the 2019 European Parliament election, the party ran posters depicting a naked white woman surrounded by Muslim men, having a brown-skinned finger placed in her mouth. The caption said: Vote for us so that Europe won't become Eurabia.'

Support for the AfD has been greatest in eastern Germany, in the former DDR regions, such as Brandenburg, Saxony, Thuringia and Mecklenburg. Many felt left out during the economic boom, which was mainly enjoyed in Western Germany. Jobs were still low-pay and insecure. Interestingly the support of PEDIGA and AfD was much greater in these eastern areas where there were fewer immigrants. AfD representatives have squared that by saying that they wanted to reserve eastern Germany for white Christians (see Fekete 2018).

Although the AfD was more popular in eastern Germany, its support was never limited to only the usual suspects of far-right voters, that is, the lowereducated blue-collar and backward-looking losers of globalization. The party also enjoyed significant support from people of other creeds, young and old, prosperous and poor, educated and illiterate (Klages 2019). The only factor apart from geography separating AfD supporters from others were their attitudes to refugees and migrants. In other words, xenophobes from all levels and swaths of society supported Alternative for Germany.

\section{Germanic Differences}

When it comes to the prominence of nativist populist parties, Austria differs from Germany in fundamental ways. As I discussed in previous chapters, such parties had for decades held a strong position in Austria. In the third wave, they still grew stronger.

Similar to trends elsewhere, in countries where nativist populists have found prolonged and significant support, the mainstream in Austrian politics was suffering. This became especially evident in the 2016 presidential election. Leading up to the vote both the Social Democrats and the conservative Christian Democratic People's Party, the ÖVP-the two had 
effectively alternated in occupying the largely ceremonial presidencyfound diminished support.

In the run-off, both were surpassed by challenger parties, the Green Party and, indeed, the far-right populist Freedom Party. This forced even mainstream conservatives to support their polar opposite in Austrian politics, the Green Party candidate, Van der Bellen. In unifying against the nativist populist candidate, the mainstream was only narrowly able to prevent Freedom Party's Norbert Hofer from being handed the keys to the Hofburg Imperial Palace in Vienna. Similar to other populists, Hofer claimed to have the people with him. You have high society behind you, he said, but I have the people.

The Freedom Party also did well in the 2017 parliamentary election. And although the ÖVP won the election, its leader Sebastian Kurz felt forced to in invite the Freedom Party into his government. Not so surprisingly it proved to be a struggle for Kurz to keep his populist partners in check, leaving the government tainted by their offensive and often racist comments. Leader of the Freedom Party, Vice Chancellor Heinz-Christian Strache, played into the Great Replacement conspiracy theory when stating that it was necessary to fend off a 'population exchange' (qtd in Shields 2019). Illustrative for his politics, the Freedom Party released a photo of Strache taken when he was attending a campaign against building a mosque in Vienna in 2009. Dressed in black, the photo showed him holding a large white cross, appearing as a warrior and saviour of the pure people (see Wodak 2015).

As I mentioned above, there are fundamental differences between the two German-speaking countries. While nativist populism has been prominent and sometimes dominant in Austria, their rise was much more recent in Germany.

\section{UP NORTH}

The range and variations of nativist populism in the Nordic countries makes the region an interesting case for understanding the phenomena more broadly. Prior to the rise of the third wave these brands of parties had only found success in two out of the five Nordic states. As was established in previous chapters, Denmark had in the wake of the Second World War started out being open, tolerant and social-liberal. However, from the 1970s two populist parties were able to turn the small Nordic state to implement perhaps the toughest legislation on immigration in Western Europe. Since the turn of the millennium, migration has become the most 
discussed topic in Denmark, mainly revolving around concerns over Muslims in this predominantly Christian society.

The cultural nationalism in the Danish Peoples Party's discourse was, for example, found in its emphasis on Christian values and the link between the state and the Evangelic-Lutheran Church. On that ground the party positioned itself as a protector of Danish culture, in a word, of Danishness (Danskhed). In doing so, DF representatives often referred to specific Danish values, which primarily consist of Christian values and family values in addition to the Danish cultural heritage, all framed within the parameters of the Danish national identity (Gad 2010).

The party clearly defined nationality by ethnicity. Still, although they were highly instrumental in the 'othering' process of foreigners, it should, however, be stressed that no evidence of outright racism was found in the party's material. While avoiding being openly racist the DF was especially skilful in separating immigrants from ethnic Danes, that is, in distinguishing between 'others' and 'us'. Its nationalism thus combined both cultural and ethnic elements.

This identity-based rhetoric was also moralist. In firmly relying on a moral frame of 'us', 'others' were negatively represented as culturally inferior (e.g. Boréus 2010). Swedish political scientist Jens Rydgren (2010) defines this as a 'neo-racist rhetoric', where national values were portrayed as being under threat from immigration.

The DF's 2009 manifesto concluded that a multicultural society was destined to be 'without inner context and cohesion' and 'burdened by lack of solidarity' and, therefore, 'prone to conflict' (qtd in Widfeldt 2015 ). To prevent such a travesty, party members argued that Danish society should be shielded from foreign impact. As a result, the presence of ethnic minorities was discursively problematized and presented as a threat to a fragile homogeneous Danish culture. Karen Wren (2001) described this depiction in Denmark as 'a historically rooted set of traditions now under threat from globalization, the EU, and from "alien" cultures'.

On law and order, the DF started out from a quite authoritarian standpoint. The party emphasized traditional Christian family values. However, when criticizing Islam for intolerance, they would move to place themselves on the side of social liberalism. In their 2009 manifesto, Islam was identified as an enemy of the LGBTQ community, saying that in recent decades, homosexuals have come under pressure from intolerant Islamic groups'. The DF vowed to work determinedly against oppression and discrimination against homosexuals. Similar to the German AfD, discussed 
above, the Danish Peoples Party had turned around to become the protector both of women and gay rights.

\section{From the Fringe}

The Danish People's Party gradually grew to become perhaps most influential political party in the country, a positioned it held for almost two decades. It also influenced most other political parties, who one after another-across the left/right dividing lines-gradually became much more anti-immigrant than before, to the extent that even the previously condemned policies of the DF were now largely upheld by the mainstream.

Supporting right-of-centre governments without accepting ministerial posts worked to the DF's advantage. The party found significant influence while also being able to distance itself from the government's more unpopular decisions. From that position, the DF was able to push through perhaps the strictest immigration laws in the entire Western world. Their polarizing division between 'us' and 'them' evolved to become a commonly shared understanding in the immigrant debate across the political spectrum.

After landing in opposition, the DF only went from strength to strength. In the 2014 European Parliament elections, they came out on the very top. In the following year, the DF won one-fifth of the vote in the general election and became the largest party on the right flank in Denmark. Under leadership of Kristian Thulessen Dahl, who had replaced Pia Kjærsgaard at the helm-she became Chair of Parliament-the DF went back to supporting Venstre's right-wing minority government.

The DF did not meet many hindrances on its road to hardening the already punitive Danish immigration policy even further. Their first demand was to stop accepting quota refugees, and then to tighten border control, for example by reinstating checks on the German border. This occurred again after an increased flow of Syrian refugees. Other European countries followed suit, for example Sweden, which even introduced temporary border control on the Øresund Bridge.

Throughout the process of acquiring mainstream acceptance, the DF firmly kept up its anti-immigrant rhetoric, as illustrated in the following two examples.

In a TV debate in November 2010 Pia Kjærsgaard suggested banning satellite dishes in immigrants' 'ghettos', because, she said, they were ugly and because they brought Muslims in Denmark access to Arabic TV channels such as Al-Jazeera and Al Arabiya (Klein 2013). 
In the wake of the Paris terrorist attack in late 2015, where Muslim jihadists mainly from Belgium and France killed 129 people, the DF's Foreign Policy spokesman Søren Espersen (2015) said in a TV interview that Western military forces should now start bombing civil targets in Syria, specifically also in areas where there were women and children.

\section{Nativist Welfare}

The DF was especially skilful in catering to its voter base. Their supporters were of a relatively low level of education, more in manual labour than specialist, more rural or suburban than urban, and either young or old rather than middle-aged. DF supporters were equally split across left and right. They had a relatively low level of trust in other citizens but believed more in their own leader than members of other parties tended to do.

When analysing the success of the Danish Peoples Party a specific winning formula can be detected. Rather than adhering to Herbert's Kitschelt's formula of combining an anti-immigrant stance with neoliberal economic policies, the DF instead combined social welfare policy and nationalist-chauvinist ideas. Here, the party struck a chord with less educated voters who in the past had voted for the Social Democrats. As I mentioned above, many right-wing populist parties in Europe have indeed tapped into the traditional voter base of social democratic parties. The DF success similarly came at the expense of the Danish Social Democrats.

As I have already discussed, the DF was successfully transformed from being a fringe party with marginal impact to become one of the most influential parties in Danish politics. Interestingly, it did this by changing the political discourse in Denmark on immigration and Islam rather than by altering its own message. Their once-condemned policies not only became fully normalized, but also much more widely supported in society. Generally, the debate had shifted away from accommodating migrants, which it had centred on in the 1960s, to measures of expelling them from the country. In 2018 a law was introduced that set longer sentences for crimes committed in immigrant ghettos. A DF member of parliament, Martin Henriksen, also proposed that children living in these ghettos should be subject to evening curfews, which would be enforced by wearing ankle bracelets (Graham-Harrison and Rasmussen 2018).

Frustrated by seeing their support bleed over to the Danish Peoples Party, the Social Democrats- the once hegemonic power in Danish politics-began to follow in the direction of the DF. During the 2015 general 
election debate, the then leader Helle Thorning Scmidt embarked on a campaign advocating imposing stricter rules on asylum seekers, and of demanding tighter demands on immigrants to adhere to Danish values. The Social Democrats voted in favour of a law allowing the state to strip refugees of their jewellery and other valuables.

A much more significant shift occurred after Mette Fredriksen assumed stewardship in 2015. With Fredriksen at the helm the Social Democrats took several further steps to abandon their former socio-liberal stance against the DF's callous immigration policy. Instead, they more or less made it their own, for instance in proposing a cap on non-Western immigrants, and of shipping asylum seekers to reception centres in North Africa.

\section{PARADIGM SHIFT}

The story of the DF's impact on the Social Democratic Party in Denmark is interesting for understanding the dynamics between populist and mainstream parties. In the so-called Paradigm Shift legislation of 2019, the Social Democrats even came to support the right-wing government's increased restrictions on immigrants. The measures included a ban on wearing the burqa, and increased the automatic repatriation of refugees out of Denmark-although by then Denmark had already been all but closed to refugees.

By the 2019 general election the DF had fallen victim to its own success and saw its support cut by more than half. The downfall was mainly caused by other parties closing in on their space, largely by copying DF policies. First, Venstre had regained some of its lost support by adopting the strict anti-immigrant stance of the DF, followed by the Social Democrats who leading up to the 2019 elections were vigorously targeting the more authoritarian working-class voters.

Simultaneously, the DF also felt squeezed from the other side, from the even further out and more extreme right. In addition to others stealing their anti-immigration policies, two new parties, positioned further out on the fringe, ran with far more extremist views than had ever been heard before in prominent Danish politics-including a call for expelling all Muslims out of the country.

The two new parties, New Right and Hard Line, emerged to challenge the DF from the fringe. New Right was much more firmly nativist, antiEU and economic right-wing than the DF, and Hard Line was outright racist. In other words, the DF was outflanked-perhaps similar to what both Glistrup and Kjærsgaard had done before. 
After themselves becoming an established party in a position of power, the DF was no longer seen as a challenger. Instead it had become the new mainstream, now contested from the outer periphery. The difference was that after they had over decades gradually been able to turn the discourse on immigration to become much tougher than before, the new challenger parties had to go much further in their defiance than their predecessors had. Leader of Hard Line, Rasmus Paludan stated that mass migration had turned Danish streets into rivers of blood-here, the previously mentioned rivers-of-blood notion of Enoch Powell is reproduced. In a video to his followers posted on YouTube, Paludan said: 'The best thing would be if there were not a single Muslim left on this earth. I hope that will happen someday. Then we would have reached our goal' (see Elabdi 2019).

Although the style of the new parties and their position in Danish politics was perhaps comparable to the Progress Party and the Danish Peoples Party when they had emerged onto the scene in Danish politics, the stance of the new parties was much tougher. As result, the anti-immigrant field had become much more fragmented in Danish politics. Only the milder version of the two, New Right, won seats in parliament. Hard Line fell just short of the threshold.

What stands out from the 2019 election is that even though the DF massively lost support, their politics was still the greater winner. In fact, political positions that previously had been kept out on the fringe were now the new normal. After the election, Mette Fredriksen came to lead a Social Democratic minority government, which continued to uphold much of the immigration policy pushed through by the Danish Peoples Party.

Not everyone was happy with this move. When accepting the Nordic Council 2019 Literary Prize, young Danish writer Jonas Eika confronted his Prime Minister, who was sitting in the front row, for continuing the former government's racist language and policies. Not only had racism become widely accepted, but he insisted that it had been institutionalized in Denmark. Eika went on to criticize other Nordic leaders in the audience, saying that many of them were contributing to the militarizing of the EU borders in a process that risked the lives of thousands of migrants.

\section{SNEAK ISLAMIZATION}

Further north, immigration had also evolved to become the issue most discussed by the Progress Party of Norway, being mentioned twice as often in the 2009 election campaign than health care, the next most frequent 
topic of party members. Party leader Siv Jensen, who had succeeded Carl I. Hagen in 2006, warned against what she referred to as 'sneak Islamisation' (qtd in Jupskås 2015). The notion alludes to a hidden process already in place, which eventually would alter Norway and turn it away from its liberal Christian roots towards becoming a Muslim-based society. In flirting with the Great Replacement conspiracy theory, Siv Jensen maintained that demands of the Muslim community, such as on halal meat being served in schools, the right to wear hijab and of public celebration of Muslim holidays, were all examples of such sneak Islamization.

Despite the tough anti-Islam rhetoric, the FrP succeeded in portraying itself as a much milder right-wing nativist populist party than those on the continent. They refused being compared to the Danish People's Party or the French National Front (now the National Rally). Siv Jensen was also successful in broadening the FrP's political platform, moving away from the initial anti-tax campaign, and later immigration, to emerging as a more normal multi-issue party, which eventually brought it closer to the mainstream. Their principal manifesto for the period between 2013 and 2017 stated that it was a liberal party based on 'the Norwegian constitution, Norwegian and Western tradition and cultural heritage, founded on the Christian outlook of life and humanistic values'. Their success in this regard is evident in the fact that they never faced similar boycotting attempts and isolation by the political establishment as did several other populist parties.

In the 2009 general election, the FrP won almost one-quarter of the vote, by then the best result of any populist party in the region, and among the very best Europe-wide. Despite striving to distance itself from extremist parties elsewhere, the FrP always had a clear populist verve. They firmly positioned themselves as defenders of the ordinary people, of 'folk flest' as the phrase goes in Norwegian. Similar to the Danish Peoples Party they successfully tapped into the voter base of the Labour Party and repositioned themselves as Norway's workers' party. Their voter base was also similar to populist parties elsewhere, mainly the under-educated working class or unemployed of the youngest and oldest voter groups. Surveys showed that the most important issue for their supporters was indeed immigration, law and order, care for the elderly and reduced taxes (Jupskås et al. 2016).

Similarly to the influence of the Danish Peoples Party in Denmark, it has also been documented how both the Labour Party and the Conservative Party of Norway gradually came to adopt much of the FrP's rhetoric on immigration (Simonnes 2011). 


\section{The Breivik EfFect}

Although the FrP was of a relatively milder kind within the realm of nativist populism, Norway has still seen its fair share or violent far-right extremism. The most horrible and traumatic incident was the terrorist attack of Anders Behring Breivik on 22 July 2011, killing seventy-seven people in a bomb blast in the administration quarter in Oslo, and in a gun massacre at the Labour Party Youth movement camp in Utøya, 38 kilometres west of Oslo. Eight were killed in Oslo and sixty-nine slaughtered in Tyrilfjorden, most of them were teenagers and very young members of the Labour Party Youth Movement. Although a lone wolf attacker, Breivik claimed to belong to the international Christian organization of Knight Templars fighting a holy war against Marxism and multiculturalism.

Breivik previously belonged to the FrP but had not found success meeting his ambition. He never got beyond Vice-Chairman of the party's youth movement for Western Oslo. He had also grown frustrated with the party being too soft on immigration.

The effect of the domestic-grown terrorist attack in Norway was one of unification, perhaps best captured in the pledge of Prime Minister Jens Stoltenberg, of more openness, more humanity and more democracy. An influential critic of welfare-oriented and social-liberal Norway, American expat Bruce Bawer (2012) wrote a book describing how the social-liberal left had used the terrorist act as a tool to silence the debate about Islam. He went so far as to accuse Labour Party supporters of being the new Quislings of Norway. ${ }^{3}$

The Breivik attack caused the Progress Party grave difficulty and threatened its hard-earned legitimacy. The party leadership campaigned vigorously to disown him and instantly toned down its anti-Muslim rhetoric. For that, Pia Kjearsgaard of the Danish People's Party was critical and said that Siv Jensen 'lacked spine' (qtd in Skarvoy and Svendsen 2011). Siv Jensen was only happy to use the opportunity to distance herself and her party from Kjærsgaard and her crew in Denmark. Still, the FrP was severely punished in the 2011 local elections.

The setback proved only to be temporary. Two years later they had won back much of their lost support and landed in government, as a junior partner in a minority coalition with the Conservative Party.

The Breivik attack revealed a hidden sub-culture in Norway, simmering underneath the surface on the Internet-a network of racist and Islamophobic groups operating around the country. One of the main 
forums for this politics was the online platform document.no, where Norwegian racists exchanged their views.

Breivik's main hero on the platform called himself Fjordman. This 'dark prophet of Norway', as he was referred to, warned that ethnic Norwegians would soon be in a minority if the political elite continued to destroy European culture and turn the continent into a 'Eurabia'. Fjordman also contributed to the web portal, Gates of Vienna. The name refers to the siege of Vienna in 1683, where Europeans defeated an invading Ottoman army. The overall narrative was of unravelling a socio-liberal cabal conspiring with Islamic forces of turning the continent into Eurabia. Breivik responded with a call to all cultural conservatives of defying the demographic infiltration of Muslims and proposed taking actions to expel all Muslims from Norway (Seierstad 2015).

Numerous other far-right movements have existed in Norway. Norwegian racism usually does not accept being racist at all. Public versions had indeed surely and squarely moved away from being biologically based, towards being culturally based. However, such former versions did still exist, as evident at the time of the Breivik trial when Roma people set up camp in Oslo. The camp suffered numerous attacks and they were described as 'rats' and 'inhuman' (see Booth 2014).

\section{Dog WhistLING}

As discussed, the initial response to Breivik's attack was severe and almost universal. But it did not lead to the demise of nativist populist tactics. An interesting example of the FrP's dog-whistle racism came before the September 2017 parliamentary elections. For several days Norway's integration minister, FrP's Sylvi Lishaug, let almost the entire political debate revolve around her planned visit to the Stockholm immigrant-dominated suburb of Rinkeby, in neighbouring Sweden. Seeing falling support ahead of the election, Listhaug played out the one card that was most likely to turn the tide for her party- the anti-Muslim card.

In front of the media cameras she warned against lenient immigration policies, like those in Sweden. Calling them 'no-go zones', Listhaug told tales of 'parallel societies having developed in more than sixty places in Sweden'. In these no-go zones, she said, were 'a large quantity of people with immigrant backgrounds'. She went on to insist that they were festered with 'conditions of lawlessness and criminals in control'. 
The Norwegian minister for integration repeatedly warned against a foreign policy she referred to as the 'Swedish condition'. The Financial Times wrote that the term was a code for 'gang warfare, shootings, car burnings and other integration problems' in the neighbouring country (Milne 2017).

Although Listhaug's statements were widely debunked and dismissed as unfounded, that did not cause her or her party any suffering at the polls. On the contrary, the FrP only saw increased support in the wake of the controversy. After rewinning her seat in parliament, she continued to uphold similar rhetoric, and in March 2018 she posted on Facebook an accusation that the Labour Party put the rights of terrorists above national security.

\section{True Finns And the Crisis}

Although Finland had surely seen its fair share of wide-ranging nationalist movements, right-wing populist parties similar to those in neighbouring countries only rose to prominence when the True Finns Party surged in the wake of the Euro Crisis hitting in 2009. Their charismatic leader, Timo Soini, was quick to position his party against EU bailout for crisisridden countries in southern Europe. Soini saw his party as a forceful channel for the underclass and asked, "why should Finland bail anyone out?' He called for Greece to be expelled from the Eurozone and said: 'We won't allow Finnish cows to be milked by other hands' (qtd in Judis 2018).

In the European Parliament election of 2009, the True Finns won almost one-tenth of the vote. Two years later they surged in the general election, landing almost one-fifth of the vote. Their success came by hijacking almost the entire political agenda when debating the Euro Crisis.

With the EU and the European Central Bank seemingly powerless, the True Finns said that the system favoured elites over ordinary citizens. One of its most vocal members, Jussi Halla-aho, wrote on Facebook that Greece's debt problems would not be resolved without a military junta.

The True Finns were able to break up a stagnant party system where three mainstream parties had for decades alternated in ruling the country. From 2009, however, Finnish politics came to a significant degree to revolve around the Finns Party and its populist politics. Prior to finding success, they had widely been dismissed as a joke, a harmless protest movement, a nuisance on the fringe of Finnish politics (Raunio 2013). Their discourse was deemed to be aggressive and crude, and the media mostly 
only saw entertainment value in them. After the 2011 election, however, they had surely become a force to be reckoned with. They clashed with the mainstream parties and called for the end of the one-truth cosy consensus politics of the three established parties. Soon, some of mainstream parties began to follow suit and came to adopt much of their anti-EU rhetoric.

In the 2015 election Timo Soini led his party to land in government for the first time. Since then, it has seen diminished support. Interestingly, unlike many other parties of a similar ilk, the True Finns accepted the populist label. Timo Soini, who had actually written a master thesis on populism, even celebrated the label, saying that their aim was indeed to please the ordinary man. Soini however refused the extreme-right label. Accordingly, the English version of the party's name was changed to the Finns Party.

Contrary to the Progress Parties of Denmark and Norway, the Finnish populists never flirted with neo-liberalism. Rather, they inherited the centrist economic policy of the SMP, which I discussed in a previous chapter. Its right-wing populism was thus never socio-economic, but rather only socio-cultural.

Three main themes emerged as the political platform of the Finns Party. First, resurrecting the 'forgotten people', the ordinary man, to prominence and speaking in their name against the elite. Second, fighting against immigration and multiculturalism. Third, stemming Europeanization of Finland.

\section{The Forgotten People}

Despite Finland being a classic Nordic welfare state based on a longstanding tradition of consensus politics, its heritage was also one of deeply rooted polarization. The dividing lines ran between East and West, Socialism and Nationalism, Urban-rich versus Rural-poor and between the Cosmopolitan and the Local.

Like the SMP the Finns Party was highly successful in exploiting the centre/periphery divide, effectively exchanging the agrarian-focused populism for a more general cultural division based on a more ethno-nationalist programme. The phrase the 'forgotten people', referred to the underprivileged ordinary man neglected by the political elite.

In this formulation, the political elite was presented as corrupt and arrogant and it was continuously accused of having suppressed the ordinary blue-collar man. Positioning themselves against the urban Helsinkibased cosmopolitan political elite, the Finns Party claimed to speak in the name of the 'forgotten people', mainly in rural areas. 
Drawing on traditional Christian values, the Finns Party discursively depicted the 'forgotten people' as pure and morally superior to the privileged elite. This sort of moralist stance was widely found in their 2011 election manifesto, including claims of basing their politics on 'honesty', 'fairness', 'humaneness', 'equality', 'respect for work and entrepreneurship' and 'spiritual growth' (see Raunio 2013).

\section{Christian Values}

The Finns Party proved to be staunchly conservative on issues like religion, morality, crime, corruption and law and order. They campaigned for Christian values, for families and family size firms, increased military and police spending, while simultaneously arguing against gender equality, openness, social diversity, same-sex marriage and sexual liberties (Norocel 2017). It was thus rather authoritarian than libertarian, tough on crime, and took a tough moralist line on drugs and alcohol abuse, cemented in Christian society and family values.

The Finns Party was surely anti-elite, but they were in no way antisystem. Indeed, the party firmly supported the Finnish state, its institutions and democratic processes, including keeping the relatively strong powers of the President. The political programme emphasized ethnonationalism, strongly focusing on Finnish national cultural heritage. They were suspicious of Swedish influence, dismissive of the Sami's heritage in Suomi, and outright suppressive in regard to the small Gypsy population.

In a classical populist 'us' versus 'them' style, a running theme was on Finnishness, of distinguishing Finns from others. Rather than a mixing of cultures within the naturally drawn nation-state, the Finns Party instead emphasized a mosaic of co-existing nations in Europe (Pyykkönen 2011).

The Finns Party promoted patriotism, strength and unselfishness and suggested that the Finnish miracle should be taught in schools, emphasizing how this poor and peripheral country suppressed by expansionist and powerful neighbours was by internal strength and endurance able to fight their way from under their oppressors to become a globally recognized nation of progress and wealth.

Like both the Danish Peoples Party and the Progress Party in Norway, the Finns Party was welfare-chauvinist. On ethno-nationalist grounds they emphasized first protecting native Finns but excluding others. On this platform, a more radical and outright xenophobic faction thrived within the party. Jussi Halla-aho, who became perhaps Finland's most forceful critic of 
immigration and multiculturalism, led the anti-immigrant faction. After an internal split which saw the back of Timo Soini and many of the more moderate faction out of the party, Halla-aho became party leader in 2017.

\section{Against (Non-Existent) Islam}

Jussi Hallo-aho has frequently been accused of racial hatred. In 2012 he was convicted for disturbing religious worship and of ethnic agitation (see Dunne 2014). When discussing immigration on his blog, he wrote that 'since rapes will increase in any case, the appropriate people should be raped: in other words, green-leftist do-gooders and their supporters' ${ }^{5}$ Hallo-aho described Islam as a 'totalitarian fascist ideology' and wrote that the prophet Muhammad was a paedophile. He insisted that Islam indeed sanctified paedophilia. ${ }^{6}$

Many other examples of defiance against immigration exist among members of the Finns Party. A well-known party representative, Olli Immonen, posted on Facebook in 2015 a photo of himself with members of the borderline neo-Nazi extreme-right group, the Finnish Resistance Movement. He wrote that he would give his life for the battle against multiculturalism. In another Facebook post, he said that he was 'dreaming of a strong, brave nation that will defeat this nightmare called multiculturalism. This ugly bubble that our enemies live in, will soon enough burst into a million little pieces (qtd in Winneker 2015).

Jussi Hallo-aho contributed extensively to the anti-immigration online forum, Homma. He said that our era would forever leave a mark on the future of the Finnish nation. 'I have strong belief in my fellow fighters. We will fight until the end for our homeland and one true Finnish nation. The victory will be ours' (ibid.).

The shift in the rhetoric from placing the EU and its bailout programme for crisis-ridden countries in southern Europe as the main external threat, to Muslim migrants replacing Brussels as the arch enemy of the Finnish people, simply follows the progression in time, as is discussed above, from the Euro Crisis to the Migration Crisis.

Many other prominent populist and extreme-right associations existed in Finland. In the wake of the 2015 Refugee Crisis, a group calling themselves Soldiers of Odin took to patrolling the street of several Finnish towns. Dressed in black jackets, decorated with Viking symbolism and the Finnish flag, they claimed to be protecting native Finns from any potential violent acts of foreigners. Perhaps it is significant that this they did despite Finland never having belonged to the Viking heritage. 
In the 2019 parliamentary elections the Finns Party became the second largest, following closely on the heels of the Social Democrats. The liberal democratic mainstream in Finland responded by forming a five-party coalition, which mainly served to keep the Finns Party out of government.

\section{The Swedish Exception}

In an attempt to explain why right-wing populists had not found similar success in Sweden as elsewhere in Europe-that is, until they did-political scientist Jens Rydgren (2002), wrote about what he called the Swedish exception. However, in 2010 the Sweden Democrats entered parliament, finally passing the threshold of relevance. Until then they had been kept firmly out on the fringe in Swedish politics.

Sweden had accepted more refugees and asylum seekers per capita than any other country in Europe. The Sweden Democrats forcefully criticized both the open-door policy and what they called a lenient immigration policy of the mainstream parties. They insisted that it had caused segregation, rootlessness, criminality, conflict and increased tension in society (Hellstrom 2016). They described the Rosengard block complex in Malmö and other immigrant communities as ghettos that had become no-go areas for Swedes. Although not true, they still claimed that the police even hesitated to patrol these areas. They implied that the Social Democrats had effectively turned these places into foreign-held territories, occupied by Muslims who were the country's greatest foreign threat, and had even partially introduced Sharia laws on Swedish soil (Åkesson 2009).

Leader of the Sweden Democrats, Jimmie Åkesson, said that Muslim refugees posed the 'biggest foreign threat to Sweden since the Second World War' (qtd in Becker 2019). He argued that Sweden should be kept as 'an ethnically and culturally homogeneous nation' and warned against the emergence of a multicultural society. The party emphasized national separatism based on biological and cultural differences.?

\section{LOOSENING THE CORDON SANITAIRE}

Prior to the 2010 electoral breakthrough, the SD had been widely dismissed as an evil outsider. In 1998, their share of the vote was not even a half per cent. In 2006 they gained some attention when almost 3 per cent of the electorate voted for them, though falling short of the 4 per cent 
parliament threshold. By 2018, their share of the vote had risen to 17.6 per cent.

The establishment in Swedish politics, other political parties and the mainstream media alike, first responded by ignoring the SD, and then by boycotting them all together, thus effectively applying on it a firm Cordon Sanitaire. Their legitimacy was also compromised by repeated incidences of aggressive xenophobic expression by party loyalists. They surely mobilized 'angry young men' into protest against immigrants, but also unwillingly attracted a following from more radical and violent neo-Nazi forces. In a demonstration in Stockholm in 1991, skinhead members of the party were heard yelling Sig Heil! The same Nazi salute was again frequently heard in 1993 at an SD-organized celebration of the late King of Sweden, Karl VII (Hellstrom 2016).

Although the SD's move from the far-right fringe of xenophobic and neo-Nazi extremism was initiated earlier, its full transformation was first achieved after young Per Jimmie Åkesson and his clan took over the helm in 2005 , just prior to his twenty-sixth birthday. They rerouted away from the party's previous neo-Nazi past and instead turned towards the model of the Danish People's Party, the National Front in France and the Austrian Freedom Party.

The new leadership set out to systematically abandon extreme and banal views such as open biological racism, for instance by stepping back its policy of deportations of all post-1970 non-European immigrants, and of reinstating the death penalty (Widfeldt 2015). They also completely redressed. The rogue demagogic neo-Nazi skinhead look, the black army boots and tattoos with Norse and Nazi imagery were closeted and exchanged for suit and tie, close shave and neat haircuts. Furthermore, members expressing extremist views risked expulsion. In November 2011, Jimmie Åkesson announced a policy of zero-tolerance for racism. Several expulsions followed.

With the rascals out, the most severe hindrance towards electoral success had been moved from their path. Slowly, and even though falling short of winning full legitimacy, the party was eventually able to reach the ears of the electorate. The Cordon Sanitaire was loosening. In fact, the SD was able to play on their stigmatization and boycott, and present themselves as victims of bullying tactics of the establishment. In the end, playing the underdog, bravely standing against an overwhelming force of the entire establishment, worked to their advantage. 
Since cleaning up its image, the SD was able to travel far from its neoNazi origins, claiming to be an alternative but legitimate voice. They positioned themselves as social conservative protectors of the Swedish national identity and traditional family values as well as advocators of law and order. Put more simply, they maintained to be speaking on behalf of the ordinary man, who the establishment had left behind. They accused the ruling elite of being preoccupied with the interests of the privileged few. Despite this effort the SD was not fully able to fend off accusations of extremism, such as of its ongoing and not so well-hidden xenophobia, and of still-visible links to neo-Nazi forces. In fact, the SD still lacked what Elisabeth Ivarsflaten (2006) referred to as a reputational shield.

\section{Equal But Separate}

In an ethno-pluralist 'equal but separate' doctrine, the SD avoided openly describing Swedish culture as superior. Instead Swedish culture and identity was portrayed as being unique and firmly separate from others. Each nation was here understood to possess one ethnically determined culture. The Swedish culture thus became a dividing line separating the native population from others in society, who were presented as a threat to internal social cohesion. Arguing that each nation embodied a singular culture based on ethnicity, they said it was the responsibility of Swedes to protect their own culture and identity from external contamination. On this ground, their 2011 manifesto emphasized turning Sweden back into a culturally homogeneous society, where the interest of the native population always came first.

In manoeuvring their way into a position of at least limited legitimacy, the real tactical breakthrough came by shrewdly adopting the social democratic notion of the People's Home (Folkehemmed). This was similar to moves made by both the Danish Peoples Party and the Norwegian Progress Party. Jimmie Åkesson claimed that the Social Democrats had abandoned their long-asserted promise of the People's Home, the allembracing welfare society. Instead, he insisted that the SD was now the true representative of the Peoples Home. The SD skilfully played on a nostalgic wish of reverting back to a simpler and happier time. This was a classical discursive creation of a Golden Age when the close connection between the ethnic people, democracy and welfare are emphasized in an exclusionary understanding of the nation (see Elgenius and Rydgren 2019). 
Vitally for achieving this discursive move, they were able to attach their own nationalist agenda of protecting the native population to the unifying metaphor of the People's Home, which in its essence contained the Swedish national identity (Hellstrom 2016). They furthermore accused the Social Democrats and other mainstream parties of abandoning the people, and only working on behalf of its own interests or for external forces. Former party leader and long-standing Prime Minister in the late twentieth century, the late Olof Palme, was placed as the main domestic culprit, accused of rapid internationalization and for promoting multicultural views.

The SD was firmly socio-culturally conservative, but unlike many rightwing nativist populist parties in neighbouring countries, it was not at all neo-liberal. In fact, the SD attacked the Social Democrats for having weakened the welfare state and for having lowered benefits resulting in the suffering of native Swedes who relied on the system. In this regard, they adopted the winning formula of the Danish Peoples Party and of Geert Wilder's Freedom Party in the Netherlands. Nordic populists indeed generally unite in embracing the newer winning formula of linking people and culture to the nation-state, that is, in protecting the redistributive welfare state for only the ethnic population, and, thus, placing migrants as a threat to it.

\section{New Master Framework}

The new master framework consisted of combining ethno-nationalism and anti-elite populism with welfare chauvinism. Jimmie Åkesson maintained that the unique Swedish welfare system could not handle too much immigration. He thus presented welfare and immigration as mutually exclusive and asked the electorate to choose. This was illustrated in an SD advert in 2010. A native woman pensioner slowly moving with her wheeled walker is overtaken by a group of fast-moving Muslim women in burqas, who cash out the social security coffers before the Swedish woman finally arrives. Their slogan read: 'Pensions or immigration-the choice is yours' (cited in Klein 2013). In a traditional welfare chauvinistic way, Åkesson and his team thus positioned themselves as the guardians of the welfare state, claiming that voting for immigrant friendly mainstream parties was a vote against the traditional heritage of Swedish welfare, while a vote for his party protected the universal welfare system. 
By discursively stealing back the metaphor of the People's Home, the SD set out to achieve several goals at once. The first was simply to capitalize on the myth of the Swedish heritage. Secondly, they positioned themselves as the true representatives of the welfare society, the defining factor of Swedish national identity. Thirdly, this was simultaneously a way to criticize the current leadership of the Social Democrats for having let down the native population for a naive celebration of multiculturalism. A final positive side effect was the portrayal of the contemporary Social Democrats as alienated elitists - out of touch both with its past and present society.

This is the classical before-mentioned three-phase discourse of nativist populists: first, Muslim migrants are placed as the threat to the ethnic and cultural nation, then the Social Democratic leadership is accused of betraying the people, while, lastly, the SD position themselves as their protectors.

\section{Persistance}

After their breakthrough in 2010 the Sweden Democrats were able to persist in Swedish politics, thus disproving the thesis of a Swedish exceptionalism. The SD was primarily a nationalistic anti-immigrant party, but after 2005 the new leadership started to broaden its scope and attempted to mobilize voters on several other issues as well. It was no longer solely a single-issue party. In line with its socio-conservative stance, the SD was initially sceptical on gay rights. Over time, however, the party repositioned itself as protectors of homosexuals against a threat to sexual liberalism accompanying mass Muslim migration. In 2010 the party published a report titled 'Time to Speak Out About Rape'. The focus was not on the crime in general, but rather on Muslim immigrants raping native Swedish women, claiming that Sweden was experiencing a rape wave, which was directly caused by immigration (see in Moffitt 2017).

The newfound social liberalism was always quite selective, and seemed mostly to be aimed against Muslim socio-conservativism. For example, when the small town of Sölvesborg, a SD stronghold, banned flying the rainbow flag often used by the gay and queer rights movements at official buildings in 2019. Council member, Louise Erixon, wife of Jimmie Åkesson, said this was because of respect for conventions.

Gradually, the Cordon Sanitaire loosened. The SD gained access to the media and was allowed to find its place on the map of Swedish politics, tolerated though perhaps not fully accepted. While surely moving to the 
mainstream, they still firmly flagged their anti-immigrant colour. This was well-illustrated in an open letter to the Finns Party in 2015, written by the leadership of the SD's youth movement, warning their neighbour of repeating the same mistakes as in Sweden. In the letter titled 'Finland, you do not want the Swedish nightmare', they wrote that over the decades Sweden had been 'destroyed' by immigration after 'undergoing an extreme transformation from a harmonious society to a shattered one'. They said that many Swedes totally opposed this system of 'mass immigration, extreme feminism, liberalism, political correctness and national self-denial' (Kallestrand et al. 2015).

This mirrored Åkesson's previous positions. In a newspaper article in 2009 he framed Muslims as the greatest foreign threat to Sweden, and, indeed, to Europe. In line with the Great Replacement conspiracy theory he claimed that Western societies were becoming Islamized and were under threat from Sharia law (qtd in Nordensvard and Ketola 2015).

In the 2018 general election the Sweden Democrats surged again to another record high of 17.5 per cent. Although the result caused a prolonged political crisis, the Social Democrats in the end held onto power in a minority government backed by other mainstream parties. After grave difficulties, the Cordon Sanitaire on the SD held, for the time being.

\section{ICELANDIC NATIONALISTS}

Until the 2017 parliamentary election, when at least two quasi-populist parties passed over the threshold and took up seats in parliament, such parties had not found significant electoral success in Iceland. In previous publications (see Bergmann 2017) I have identified three main reasons halting their rise. First of all, nationalism was never a discredited ideology in Iceland, like it was in most other Western European countries after the Second World War. The small island country gained its independence from Denmark in 1944 and its postcolonial national identity was firmly based on nationalistic sentiments (Bergmann 2014a). There was thus no need to challenge the political establishment with nationalistic views from the fringe, as nationalism had never been marginalized.

Secondly, nativist populist parties in Europe had found most success when opposing mainly Muslim migrants. Muslims are scarce in Iceland and there are no areas where the semantics of an Arab culture dominate the scene. And thirdly, populist parties have usually found success when 
under leadership of charismatic leaders. Until recently, far-right populists in Iceland were rather unlucky in that regard.

However, the Financial Crisis which hit Iceland especially hard in 2008 brought political upheaval and unleashed quite a few populist actors (Bergmann 2014a). Through the so-called Pots-and-Pans Revolution several protest movements emerged. In 2009, the Citizens Movement entered parliament; later it was succeeded by the rather left-leaning quasipopulist Pirate Party.

On the wave of the crisis, a completely renewed leadership also took over the country's old agrarian party, the Progressive Party (PP), which was rapidly retuned in a more populist direction: geared against foreign creditors, international institutions and eventually partly towards antiMuslim rhetoric - even in the absence of a significant Muslim population.

In 2013, the young and new PP leader, Sigmundur Davíð Gunnlaugsson, came to head a government in a coalition with the mainstream previously hegemonic right-wing conservative Independence Party — which had been ousted in the Pots-and-Pans Revolution. Gunnlaugsson had risen to prominence on the canopy of public protests against foreign governments and creditors who were pressuring Icelanders to shoulder the debts of the fallen Icelandic banks abroad (Bergmann 2016).

After being exposed by Wikileaks in the so-called Panama Papers for his family holding a small fortune in unregistered offshore accounts, Gunnlaugsson lost leadership in the party. He responded with constructing his own, the Centre Party, which was a more clearly nativist populist forum. Gunnlaugsson was also prone to upholding a wide range of conspiracy theories. He insisted that George Soros had orchestrated his demise by leaking the Panama Papers. In the 2017 general election, the Centre Party won more than one-tenth of the vote. It was then elevated further in 2019 when manufacturing controversy around the EU energy legislation, which Iceland adopted through the EEA agreement.

Another quasi-populist party also found support in the 2017 election. The Peoples Party was prone to uphold welfare chauvinism. Its leader, Inga Sæland (2016), counted the cost of admitting asylum seekers versus helping poor Icelanders. She insisted that while skint Icelanders suffered hardship, asylum seekers, funded by the state, were living in comfort. Rhetorically she asked whether that money might instead be better used by helping poor Icelanders. This is a classic case of creating false oppositions.

Despite the lack of a significant Muslim community in Iceland, there were still a few movements that made campaigning against Muslim 
influences their primary purpose. In 2017 I for example attended an event where Robert Spencer, founder of Jihad Watch in America, was a keynote speaker. When I arrivied I felt a tense ambience in the packed conference room. Herds of stern looking security guards were roaming around, ready to silence anyone who might protest against the message on offer. I was at the time collecting data for the research published in this book. After the meeting concluded I asked to pose a couple of questions to Mr Spencer. I was not only refused but fast turned away by the heavily built guards, and in no uncertain terms made to exit the premises. The foreign guests left via a side door and were immediately whisked away in a waiting car. The heavy handling was highly unconventional for other public gatherings in Reykjavik.

\section{An Illiberal East}

With the fall of the Berlin wall, many of the countries in Eastern Europe who were escaping from communism entered onto a path of far-reaching economic restructuring. They would even apply neo-liberalism policies more vigorously than had been done in the free market states in Western Europe. As I discussed in the previous chapter, this transformation brought serious hardship to the public. When the promise of liberal democracy failed to deliver the anticipated prosperity, many people grew frustrated and authoritative nationalists were shrewd in exploiting the situation. This was the case in the Visegrád countries. Populists came to power in all of them, the Czech Republic, Hungary, Poland and Slovakia.

As I discussed in the previous chapter, Hungary was in the 1990s firmly en route to liberal democracy within the international architecture of crossborder institutions. On that long winding road, the public was however growing frustrated with the lack of improvement in their living standards. Inequality was growing and the grotesque coteries of the nouveau riche were showing off their wealth. Large swaths of the general public felt left out. And when the ruling class was increasingly seen as being in bed with the new breed of capitalists, the common man was not only getting fed up, many were also getting ready to consider other routes than only those leading to liberal democracy — which had, up until then, not provided the Hungarian people with much economic progress.

After winning a full majority in the 2010 general election, in the wake of the Financial Crisis biting hard, Fidesz party leader, Viktor Orbán, started to consolidate state power into his own hands, for example by controlling and oppressing free media, ousting liberal academia, reducing 
judicial independence and tightening control of the entire state apparatus. He filled the constitutional court with his own trusties and rewrote the constitution as well as gerrymandering electoral districts for his own advantage (Levitsky and Ziblatt 2018). Orbán controlled the state media by placing it under a Fidesz-led council. Private media outlets and journalists were also made to register with the government. If the authorities found their reporting not being balanced enough they could be fined. Next, Orbán prevented the opposition from getting their messages across, for example by banning campaign material in private media.

Gradually, Fidesz was able to turn Hungary towards a governmental system that Orbán himself described as a Christian illiberal democracy. Hungary in effect became a one-party state. Orbán stated that democracy should be hierarchical rather than liberal. His vision was for Hungary to become an 'illiberal new state based on national foundations' (qtd in Mahony 2014). Orbán celebrated Donald Trump's victory in the US, saying that his election marked the transition from liberal non-democracy to real democracy. In essence, his vision was for an authoritative democracy without individual civil rights. In a hierarchical illiberal democracy the leader is trusted to interpret the will of the people.

\section{The Ethno-Centric View}

Victor Orbán's understanding of the Hungarian nation was also highly ethno-centric. Speaking at an ethnic Hungarian summer camp in Romania in 2014, he said that the Hungarian nation was not just the sum of individuals in the country. Rather, it was an community that 'must be organized, reinforced and in fact constructed' (qtd in Judis 2018).

In wake of the Syrian Refugee Crisis, Orbán took an even firmer stance against migrants, refusing to adhere to collective EU response and instead hired thousands of border hunters while fencing of the Hungarian border with a gigantic defence wall. He said this was his duty, otherwise the Hungarian nation would die out. Orbán placed refugees seeking asylum in Hungary as a threat to the ethnic Christian Hungarian nation, insisting that Hungary should be kept for Hungarians alone. In an address in 2018, he stated that 'we do not want to be diverse and do not want to be mixed: we do not want our own colour, traditions and national culture to be mixed with those of others. ${ }^{8}$

In his fight against asylum seekers, Orbán launched a renewed attack on George Soros, also discussed in previous chapters, who had in the 2015 
Refugee Crisis advocated that Europe should accept migrants from the Middle East. Orbán insisted that Soros was, aided by the EU, seeking to ruin the Hungarian nation by way of migration. The government splattered posters of Soros around the country, for instance reading: 'Soros wants to transplant millions from Africa and the Middle East. Stop Soros.' Another simply said: 'Let's not let Soros have the last laugh' (Judis 2018). Some of the posters suggested that Orbán was indeed controlling the European Union behind the scenes.

During the Coronavirus Crisis of 2020 Orbán used the opportunity to rush through emergency legislation which in effect gave him powers to rule by decree. Parliament was sent home and anyone found disseminating information which authorities deemed being false or disturbing could be incarcerated. Hungary had travelled far from core criteria of EU membership, those of respecting human rights and the rule of law.

\section{Two OF A Kind}

Over in Poland, authorities under Jaroslav Kaczynski and his largely hegemonic party in the post-communist era, Law and Order, have more or less followed suit in the direction of Fidesz in Hungary, for example by increasing government control over state media and packing the Supreme Court with cronies. Poland was turned away from the path laid by Solidarnosc towards market economy and liberal democracy, to become one of the most polarized in Europe.

Nationalist sentiments in Poland, like in Hungary, often rest on ideas of victimhood and foreign oppression. Kaczynski also defined the Polish national identity on ethnicity and pointed to refugees as contaminating the Polish people. He insisted that Syrian refugees brought new and dangerous diseases to Poland and argued that Europe was facing a serious crisis of consciousness, saying that accepting refugees showed the willingness of EU leaders to sacrifice European cultural and ethnic identity.

Finding increasing support at home and seeing similar-minded parties flourishing in many other Eastern European countries has galvanized both Hungary and Poland in defying the European Union's immigration plans. Orbán rejected the EU refugee quotas, saying that the EU's migration policy had failed: 'It is clear that the European people don't want immigration, while several European leaders are still forcing the failed immigration policy.' 
Interestingly, given the history of race-related victimhood in the Second World war, anti-Semitism was also on the rise. The right-wing newspaper, Tylko Plolska (Only Poland) for example ran a frontpage story explaining to its readers how to spot a Jew, listing anthropological features and character traits. A headline read: 'How to defeat them? This cannot go on' (qtd in Osborne 2019).

Both Hungary and Poland have been in violation of the Copenhagen criterions of the European Union, which lays out the bloc's fundamental accession requirement rules, such as respecting democracy, human rights and the rule of law. In autumn 2018, the European Parliament triggered against Hungary its Article 7 procedure for countries found being in breach of democratic governance and for human rights violations.

Domestically, Orbán was then able to use this external interference to play up fears of renewed foreign oppression. Catering to national myths as discussed in the previous chapter, the EU was positioned as yet another foreign power seeking to dominate Hungary and erode its sovereignty.

\section{Conspiratorial Russia}

Russia is the country in Eastern Europe where this trend away from the promise of liberal democracy has perhaps gone the furthest, turning this Eurasian superpower into an at least quasi-authoritarian regime. After coming to power, Vladimir Putin gradually started to abandon Boris Yeltsin's policy of bringing Russia into the international family of liberal democracies. Instead, Russia has travelled far on the path of post-ColdWar illiberalism. On the way the West was, after having for a short while been considered a partner in a shared quest for a liberal future, redefined to again become the arch-enemy of Russia. One of the most powerful tools in this turn was the use of conspiracy theories, which always have been a prevalent feature in Russian culture.

Anxiety and feelings of powerlessness in post-Soviet Russia led to a growing nostalgia for past Soviet times and a simultaneous rise in antiWestern attitudes. Ilya Yablokov (2018) illustrates how tales of antiWestern attitudes framed the nation-building discourse in Putin's Russia and that by doing so, the strong leader was able to suppress dissident voices. The European Union was especially targeted and portrayed as decadent and hostile. The West was in general treated as the ultimate Other, 
seeking to prevent Russia from flourishing. This narrative helped to reinforce two vital notions. One was of Russia being different from the West, and that it should not imitate its liberal democracy. The second notion underlined Russia's greatness, which, vitally for the story, was that the West was aiming to destroy Russia.

I can take an example from my own experience. In 2015, I was invited to give a presentation at the Moscow State Institute of International Relations, run by the Russian Foreign Ministry. In discussions with governmental officials, faculty members and students alike they all insisted that the West-mainly Germany, France, the United Kingdom and the United States - was actively undermining the Russian state a by variety of means. Not least because of that, they insisted that Russia had to develop its own kind of democracy instead of adopting the liberal style of the West-which, they said, was just ongoing Western colonialization. In our conversations they argued for an alternative model, what they called an illiberal and authoritative variety of democracy, which would fit much better for Russia and its political heritage. When challenging them on how it would work, I came to understand that meaningful democratic-decision making was not a core ingredient of the governmental system they described to me. In fact, calling it a democracy was just another oxymoron.

For this turn, the Russian state media played a pivotal role. The Moscow-based state-controlled English language 24-hour television news station Russia Today (RT), was made available to a global creed of conspiracy theorists. They would welcome onto their airwaves almost anyone with a story undermining the credibility of the West, including the notorious far-right commentator Alex Jones. RT presenters seriously discussed covert actions of, for example, the Bilderberg group, 9/11 Truther Movement theories and stories of climate change conspiracies, treating them as credible news (Byford 2011).

Far-fetched and unfounded conspiracy theories of aggressive outsiders were actively promoted by the Kremlin for their domestic political gain. As Guardian columnist Natalie Nougayrede (2015) writes, this rhetoric centres on the notion that Western powers were engaged in covert manipulations with the intent of ultimately 'dismantling the very statehood of Russia'. Collectively, this turn constituted a systemic campaign of misinformation upheld by the authorities themselves. In an attempt to capture this kind of politics, Peter Pomerantsev's (2015) unauthorized biography of Vladimir Putin was titled Nothing Is True and Everything Is Possible. 


\section{External Aggressors}

This discursive creation of external plots served to rally support behind the Kremlin in fighting against their internal political opponents. By depicting domestic dissidents as covert aggressors from abroad, Putin and his clan not only claimed the right to crush nonconformist voices domestically, but also insisted that the Russian state was obliged to do so. Taking them on at home was thus part of the good fight against foreign enemies.

This political construction furthermore provided the authorities with means to blame almost anything that went wrong on the external enemy and its internal covert collaborators. In this vein Vladimir Putin was prone to point a finger against what he perceived to be continuous US-led aggression against Russia.

This is a classic case of how a nativist populist places himself as a protector of the nation against a foreign threat which he himself had discursively created. In applying this simplistic dualist worldview, the nativist populist can also turn against any disobedient domestic voices, as they are simply branded as traitors of the people in the good fight.

In these cases, the leader equates himself with the people against both external threats and domestic traitors. Discursively, the people and their leader become a single entity. This is similar to that which Donald Trump attempted in the United States, by branding the media as the enemy of the people.

As has been discussed, fears of Western subversion became a key instrument for the social cohesion of the Russian nation. Gradually there was a shift from fears of Western forces as the primary threat to the country, towards also including fears of migrants. This turned into an evolving belief in the Great Replacement conspiracy theory, that external forces were now also plotting to ruin Russian society by migrant infiltration.

\section{Traitors Within}

This leads us to the importance of the notion of traitors within for understanding contemporary Russian politics. The young women of the protest punk band Pussy Riot, for example became in handy as perceived perpetrators. In February 2012, five young women attempted to perform what they called punk-prayer in the Cathedral of Christ the Saviour in Moscow. The title of their song was telling for their aim: Mother of God, Drive Putin Away. Ahead of the presidential elections, the all-girl punk band became a 
leading voice of much larger ongoing protests against Vladimir Putin's regime. At first, the young women were dismissed as some sorts of hooligans. But soon after the stunt in the Moscow cathedral they were treated as enemies of the Russian nation. Three of them were arrested and sentenced to two years in prison. Since then, several members of the band have faced repeated arrests and incarcerations.

To deal with the domestic protestors, Russian authorities launched an aggressive media campaign, in which the young Russian women were depicted as being agents of a Western-led plot to undermine the very Russian statehood, and, indeed, to prevent Russia from fulfilling its full potential at home and in the world. In these invented stories the domestic dissidents were directly linked to foreign intelligence agencies and branded traitors of the people, posing an existential threat to the Russian nation and its cohesion.

Within the Kremlin many argued that Pussy Riot was a Western revenge plot, sent to demoralize the Russian nation, and to demonize the Russian government for standing up to Washington's intention to destroy Syria. In this vein, the regime was able to assert that they were faced with disruptive forces that threatened the very unity of Russian society.

In this discursive creation, domestic criticism of the Russian regime was dismissed as mere undermining tactics of Western forces, with the aim of weakening Russia for the West's own geopolitical gain. By this rhetorical internal division of 'us' and 'them' authorities could treat the domestic protestors as foreign infiltrators who were undermining an otherwise united Russian nation. By depicting them as foreign conspirators, the Kremlin was able to portray dissenting actors as posing a major threat to Russian statehood. Members of the domestic punk band were via this method treated as invaders who aimed to destabilize, and, indeed, to emasculate Russia.

The Kremlin went further and dismissed the young girls of Pussy Riot as immoral deviants, sexual perverts, witches, blasphemers and provocateurs who were supported by the West and utterly alien to the ordinary Russian people (Yablokov 2014). Via media reporting, the young women of Pussy Riot were discursively turned into 'others', and thus made distinct from the Russian nation.

The case of Pussy Riot was only one of many leading to a highly conspiratorial discourse following in the Russian media. Another case in point was the treatment of opposition leader Alexei Navalny, who on dubious grounds has repeatedly been incarcerated and barred from standing in 
elections. Almost all domestic dissenting voices were subsequently portrayed as part of the overall Western conspiracy of ruining Russia. In the media campaign, the protesters were depicted as being a conspiring minority within the nation, perhaps much like a cancer that needed to be uprooted. Furthermore, all criticism from abroad of the harsh treatment of the young women could be scorned as part of the external plot. Indeed, critical reporting from abroad was taken as proof of the Western-led conspiracy.

\section{Misinformation TACTICS}

In its dispute with the West, Russia has been accused of deliberately applying misinformation tactics in order to discredit Western authorities. The Kremlin was for instance found to have interfered in both the Brexit referendum debate in the UK in 2016 and the US presidential elections later that year. They have also been caught funding actors in Eastern Europe who cast doubts on the European Union, for instance in the Czech Republic, Slovakia, Hungary and Poland (Snyder 2018). Russia has also supported anti-EU far-rights populist parties in Europe, including Le Pen's National Rally in France. The aim of these actions was to disrupt the unity of liberal democracies of the West. It is estimated that before the European Parliament election in 2019 more than half of the voters had been exposed to disinformation campaigns emanating from Russia (Scott 2019).

During the Coronavirus Crisis of 2020 many similar conspiracy theories were detected coming out of Russia. One insisted that the virus was a biological weapon made in America by the CIA. Another which was widely discussed by pro-Kremlin actors on Russian state TV maintained that the UK was sitting on a vaccine and would only roll it out at the height of the crisis, for their monetary gain.

The Kremlin forcefully supported Donald Trump for US President, openly and behind the scenes. One of the most influential ideologues of the Kremlin's quest for a spiritual rise of Russia as a Eurasian superpower was Alexander Dugin. Prior to the US elections he urged American voters to support Donald Trump and posted a video titled: 'In Trump We Trust'. Although the extent of the operation is not known, it is uncontested that the Kremlin actively sought to get Trump elected. Sources close to the Kremlin leaked large amounts of emails that had been harvested from Hillary Clinton's server. The timing of their release in July 2016 clearly hurt her in the elections (Snyder 2018). 
The office of the United States Special Prosecutor, Robert Mueller, indicted thirteen Russian nationals and three Russian companies-including a notorious Troll Factory in St Petersburg called the Russian Internet Research Agency. The indictment issued in 2018 stated that the Petersburgbased agency had conspired to 'defraud the United States by impairing, obstructing, and defeating the lawful functions of the government through fraud and deceit for the purpose of interfering with the US political and electoral processes, including the presidential election of 2016'.

\section{Troll Factories}

Robert Muller's investigation found that the Russian computer Bot Farm had invested large amounts of money interfering in the US election debate. The investigation found that these Troll Factories had continuously spread pro-Donald Trump propaganda and fake news on social media platforms such as Facebook and Twitter. In 2017 alone a task force set up by the EU mapping fake news coming out of Russia-the East StratCom groupdetected 1310 such fake news stories of various kinds. ${ }^{10}$

One insisted that Angela Merkel was the secret daughter of Adolf Hitler. Another said that Sweden was on the verge of a civil war. Many of these stories ridiculed the political correctness of the West. One cited a fabricated directive of the European Union regulating children's formations of snowmen. The story said that anyone building a white human from snow would also have to include a yellow and a black version, otherwise the EU would fine them $€ 5000$ for racism.

Several of these stories also spoke to the perversion and demoralization of the West. Denmark was said to have legalized animal prostitution. Another story said that the mainstream media was silencing the grim fact that due to immigration rapes in Sweden had increased by a 1000 per cent between 2015 and 2017. According to these stories, the Swedish authorities were no longer investigating rapes committed by refugees (Palma 2017).

Sweden was a popular source for such stories. One claimed to unravel a secret plan of Sweden's Foreign Minister Margot Wallström, to sterilize all white men in Sweden to prevent them from breeding further. Incidentally, that was never true, and reported rapes in Sweden in 2017 were up by only 1.4 percent from 2015 .

Among the main themes identified in these stories was of a US plot to occupy Europe. One of these stories reported that the US Air Force had in 2017 bombed Lithuania. Another indicated that French President Emmanuel Macron was a secret agent of the US Department of the 
Treasury. The report said that Macron was backed by homosexual lobbyists and also by the wealthy Rothschild family. In another version authorities in Berlin were also accused of a plot to turn Europe into a German colony. ${ }^{11}$

In these stories the West was systematically treated as the ultimate Other, as hostile and seeking to prevent Russia from flourishing. The Kremlin flirted with many conspiracy theories catering to this notion. One was upheld by Putin's crony Vladimir Yakunin, former head of the Russian railways state company, who maintained that the West was deliberately spreading homosexual propaganda around the world in order to reduce birth rates in Russia, and therefore weakening the Russian state (Snyder 2018).

In these stories, Russia, however, was usually seen as the innocent and moral actor under siege from an iniquitous and violent Western aggressor. Putin was prone to elevate Russia from not only being a nation-state on planet earth but also into some kind of divinity. Once he even described Russia as a spiritual condition (ibid.).

Many of the stories vilifying the West were centred on Germany, the epicentre of post-war liberal democracy. One insisted that Germany was a deteriorating but aggressive state in support of Nazis in Ukraine. According to the story, Germany was, via a large scale Nato build-up in the Baltics, planning to invade St Petersburg.

Via this depiction, Russia was able to present its own invasion into Ukraine, when annexing Crimea in 2014, as a defensive act against Western aggressors. The Kremlin ran a series of fabricated stories claiming that proWestern authorities in Kiev were crucifying children. As result, the fight of Russian soldiers across the border was merely in protection of the innocent against an external evil.

\section{GaYropa}

A common theme of these stories of the West harming Russians revolved around Europe having fallen into the hands of immoral homosexual authorities. This was the notion of Gayropa. One story revolved around a Russian mother in Norway who after divorce had lost custody of their children to her Norwegian husband. Irina Bergseth became a media sensation in Russia, with her story of mischievous Norwegian authorities stealing Russian children and giving them to homosexual domestic nationals.

More broadly she described Scandinavia as having been gayofied and maintained that Russia was now the last bastion of traditional values, the 
only one opposing 'a sodomite dictatorship' which Europe had become. Her message fitted well into the dominant Russian narrative, which represented non-heterosexuals as sex-radicals. Often the story implied that the imperialist West was imposing gay-ism to undermine Russia (Persson 2015).

Many of these stories revolved around the tarnished morals of the West. One insisted that in Sweden schools were forcing all pupils to pray to Allah. Another said that Christmas was being renamed the 'Winter celebration' to avoid offending Muslims in Sweden. The root to that story was a single headline in the Swedish daily Sydsvenskan, which referred to Christmas as a 'winter celebration'. Several Russian web outlets followed up on the story by publishing a video from a Western-style shopping mall where a mob of people was ruining a Christmas tree, apparently in an attack on a Christian symbol (Lacarpia 2016). Several Coronavirus Crisis conspiracy theories depicted the West as inept and dysfunctional, for instance, indicating the dissolution of the European Union as a result of mismanaging the crisis.

\section{BreXit, BreXit, BreXiT}

The debate leading up to the vote in the United Kingdom of leaving the European Union-Brexit-in June 2016 proved to be highly nationalistic, populist and conspiratorial. Of course, wanting to the leave the EU is not in itself populist. Not at all. It is a perfectly legitimate political position to hold, also keeping in mind that the UK had for long been somewhat hesitant in regards to the increased supranational nature of the EU. However, in the referendum campaign the aforementioned threelevel rhetorical tactics defining nativist populists were all clearly present: Discursively creating an external threat, blaming the elite of betraying the people and positioning oneself as the true defender of the nation. Through the progression of the debate, the external threat pointed to would interchangeably be the European Union and/or migrants. The Labour Party leadership and the Remain elite of the Conservative Party were cast as traitors to the people. Vote Leave campaigners, as well as the more rogue UKIP leadership, then positioned themselves as the liberators of the British people.

There was also an interesting shift in the positioning of the external threat, depending on whether it was seen stemming from the EU or from immigrants. In arguing against migration, the EU would be placed in the role of the elite that was betraying the people. However, oftentimes the 
EU would itself also be targeted as being the outgroup threatening British identity. As I will illustrate on the coming pages these rhetorical manoeuvrings were tailored to meet each argument when it fitted the debate.

As would also be the case in the US presidential elections later that year-discussed ahead in this chapter-sophisticated misinformation tactics were used to influence voters. The data analysis company Cambridge Analytica was accused of manipulating people's personal data on social media to target individual fears directly, irrespective of reality. Here are some examples of the misinformation tactics openly applied in the Brexit debate.

'Let's give the NHS the $£ 350$ million the EU takes every week.' This was the message on the first billboard of the Vote Leave campaignunequivocally insisting not only that EU membership costed UK taxpayers this vast sum of money every week, but also that the enormous amount would be available to fund the UK National Health Service after leaving. The same message was printed widely in Brexit campaign materials, famously, for example, on the side of their campaign bus. At best, this was very misleading. Not only was this a gross figure blown out of all proportion and did not take into account returns through EU programmes, but also did it not even deduct the so-called UK rebate, adding to the calculation amounts that never even left Britain.

This kind of depiction fits with classic populist positioning. EU membership was here linked to the NHS being underfunded. In other words, this is a classic case of false polarizing, where funding the NHS properly was directly linked with leaving the European Union. Furthermore, this served to oppose 'Us' with 'Them', protecting our NHS against paying into the foreign EU. By this positioning, the EU was placed as an external threat to proper healthcare in Britain. Unelected EU administrators were here placed as an external authority, burdening the British with their corrupt ways. Vote Leave chief strategist Dominic Cummings said that everyone knew that 'Brussels is a very corrupt place full of bureaucrats who have done no good to this country' (qtd in Harrison 2019). In this vein, the Vote Leave slogan of 'take back control' speaks directly to the notion of fighting an external power which had sucked authority from the country. This was simultaneously a call for bringing power back to the people and of resurrecting Britain to its former glory. In many ways this was a nostalgic turn back to previous times when free and independent Britain was a world-leading empire. Boris Johnson, who came to lead Britain through in the Brexit conundrum, indeed played on these nationalist notions, both prior to and after becoming UK Prime Minister. 
Brexit has also to be examined in relation to the severe austerity which the UK underwent in the post-Financial Crisis era. Before the vote in 2016 the government had implemented several measures to meet costs inhered by the 2008 crisis. This led to monetary fatigue in many deprived places. Correspondingly, the support for Brexit was greatest in areas most severely hit by the crisis (Becker et al. 2017).

\section{TAKIng Back CONTROL}

Another classic tactic applied in the Brexit campaign was in discrediting specialists that called out the false information upheld in the campaign. When criticized by many specialists for his simplistic and antagonistic attitude to the situation, a leading Brexit campaigner of the Conservative Party, Michael Gove, replied: 'I think the people in this country have had enough of experts' (qtd in Bennett 2016). With his words, Gove applied at least two rhetorical fallacies, a red herring deviation from the topic, and also an ad hominem attack on the accusers.

Instead, he insisted that after the referendum the UK would instantly 'hold all the cards', and that it would be incredibly easy to make a great deal with the EU (see Henley et al. 2018). The opposite turned out to be true. When Boris Johnson rose to power in 2019, he made Gove his de facto deputy Prime Minister in control of no-deal preparations. It can be argued that suspicions of specialists had made the government slow to respond to concerns leading up to the Coronavirus Crisis of 2020, which hit the UK especially hard.

Taking back money was but one of many messages that were only loosely linked to reality during the Brexit debate. Leading up to a visit by US President Barack Obama, who was expected to come out against Brexit and say that in the case of a leave vote, it would take a long time to negotiate a trade deal between the USA and the UK, many of the Brexiters took to undermining the US president's credibility. Ahead of the visit, in the tabloid The Sun, the then London Mayor Boris Johnson said that due to Obama's part-Kenyan ancestry, Obama had a dislike of the British Empire. To underpin the claim, Johnson insisted that precisely because of that reason Obama had removed a bust of Winston Churchill from the Oval Office in Washington upon taking office as US President. After Johnson was criticized for covert dog-whistle racism UKIP leader Nigel Farage came to his defence. Farage wrote that Obama indeed 'bears a bit of a grudge against this country because of his grandfather and Kenya and colonialization' (qtd in Bennett 2016). 
Boris Johnson proved to be highly conspiratorial during the campaign, for example when stating that the EU had the same goals as Adolf Hitler, that of creating a European superstate: 'Napoleon, Hitler, various people tried this out, and it ended tragically. The EU is an attempt to do this by different methods' (qtd in Ross 2016). After becoming UK Prime Minister in summer 2019, Mr Johnson restated the similarity between the aims of the EU and Nazi Germany.

$\mathrm{Mr}$ Johnson was not new to concocting stories about the EU. When he was Brussels correspondent for the Daily Telegraph in the 1990s, he became infamous for fabricating funny but false news stories about the EU. One of his frontpage stories insisted that the then President of the European Commission, Jacques Delors, was planning to rule Europe. Johnson however mainly made a name for himself with more quirky stories, ridiculing the EU. One ran under the headline 'Italy fails to measure up on condoms.' Johnson mockingly wrote that 'Brussels bureaucrats have shown their legendary attention to detail by rejecting new specifications for condom dimensions.' He said that this was 'despite demands from the Italian rubber industry for a smaller minimum width'. Johnson concluded that the whole thing had left 'Italian egos smarting' and finished by quoting an official spokesperson, Willy Hélin, who he said insisted that 'this is a very serious business' (qtd in Rankin and Waterson 2019). Johnson was notorious for fabricating quotes, but that did not stop his highly entertaining stories being picked up in papers around the continent, shaping the minds of many that read them. Mr Johnson was indeed a pioneer in the industry of fabricating political stories, and he helped to pave the way for the later avalanche of fake news.

There were also those that went much further in Brussels bashing. UKIP's Gerard Batten seemed to believe that the EU was conceived by Nazi Germany (Stone 2016). He also insisted that the notorious Bilderberg group was secretly plotting to prevent Britain from leaving the EU. It is worth mentioning that after Nigel Farage left UKIP and formed the Brexit Party, UKIP became much more clearly nativist populist, and even joined up with several more authoritarian and racist movements.

\section{The Muslim CARD}

Another conspiratorial aspect of the Brexit campaign was related to fears of the possible accession of Turkey to the EU and, thus, of increased Muslim migration to the UK. While dismissing the fact that all EU 
member states hold a veto of new members, Vote Leave still insisted that the UK would, in practice, not be able to stop the Turks from getting their hands on EU passports.

In the third wave of post-war nativist populism, the UK Independence Party had surpassed the British National Party (discussed in the previous chapter) and firmly occupied the populist space in the country. Its leader Nigel Farage had become the primary voice advocating for Brexit. He forcefully maintained that 75 million poor Turks were on the verge of gaining access to the UK, 'to use the Health Service, to use our primary schools, to take jobs in whatever sector it may be' (qtd in Bennett 2016). They insisted that the Brexit vote was indeed a referendum on the massive migration of Muslims into the UK.

This was in the midst of the Refugee Crisis stemming from the war in Syria. Farage went on to argue that even combatants of the terrorist organization Isis would also filter through to the UK with Syrian refugees coming from Turkey. Here, the positioning of the European Union had shifted. It was no longer placed as the external threat, such as when accused of undermining the NHS. When it came to migration, the EU was instead cast as a traitor to the British people, facilitating uncontrolled flow of Muslim migrants to the UK. Nigel Farage referred to them as 'hordes' of foreigners' (qtd in Harrison 2018). The discourse was highly xenophobic. Migrants were linked to loss of identity and the erosion of British culture.

In a speech promoting Farage's message, prominent Conservative Party member Theresa Villiers said: 'If people believe there is an immigration crisis today, how much more concerned will they be after free movement is given to Turkey's 75 million citizens?' Former Conservative Party leader Ian Duncan Smith similarly maintained that the EU had made it very clear that Turks 'are going to get free travel and then enter the EU'. In a statement, Vote Leave went on to state that the high birth rate in Turkey would lead to one million Muslim Turks coming to the UK within eight years (Bennett 2016). A prominent Vote Leave campaigner Penny Mordaunt said that a vote for remain was a 'vote to allow people from Albania, Macedonia, Montenegro, Serbia and Turkey to move here freely when they join the EU soon' (Lister 2016).

Messages playing on these largely unfounded fears were actively built into the campaign material of Vote Leave. Neither country was on any kind of route towards EU membership. Still, with the focus in the campaign shifting to imagined Turkish membership and invented increased 
Muslim migration into the UK, the polls started to move in the favour of Leave.

A third poster showed a photograph of a seemingly endless flow of refugees crossing through the Balkans, mostly young males. Its text read: 'Breaking point - the EU has failed us all.' At the bottom, the message continued: 'We must break free from the EU and take back control of our borders.' Collectively, this constitutes a systemic campaign of misinformation.

When accused of racism, Farage used the well-known rhetorical fallacy of attacking the accuser, saying that anyone calling his party racist was, directly because of that, part of the establishment.

Communication studies have shown that coverage of Muslims in UK media is predominantly negative, especially in outlets supportive of the Conservative Party (Waterson 2019). Accordingly, surveys showed that majority of Tory Party members believed Islam was generally a threat to Western civilization, and a threat to the British way of life.

\section{A Violent Turn}

As has been seen in many other cases, such as with the Breivik attack in Norway and by the aforementioned shooters in Christchurch and El Paso, this sort of rhetoric can lead to violence. The misinformation discussed above was among the political messages that Thomas Mair proved to be overtly susceptible to. A week before the vote he pulled out a sawn-off rifle and knife and shot and stabbed a forty-one-year-old woman who in the early afternoon was heading for the library entrance on the Market Street in his West Yorkshire town. Jo Cox was a Labour Party MP on her way to a constituency surgery. She died as result of multiple wounds and Mair was sentenced to life in prison without the possibility of pardoning.

Jo Cox was a staunch believer in European integration and a firm supporter of both immigrants and a multicultural British society. Her killer had come to believe that left-wing liberals in politics and in the mainstream media were responsible for much of the world's evil, and, indeed, for his own misfortune (Bennett 2016). Mair was a racist who believed in the Great Replacement conspiracy theory. He was obsessed with notions of white people facing increasing aggression. And he had the utmost contempt for those whom he called white traitors of their own people. In his eyes, Cox was one of these left liberals responsible for ruining the Western world. He saw her as one of 'the collaborators' of these external aggressors and a 'traitor to white people' (Cobain et al. 2016). 
Thomas Mair was plugged into many far-right groups, including the notorious English Defence League, where he attended many gatherings. His house was filled with Nazi memorabilia and white supremacy literature. Noticeably, he had kept press cuttings about the case of Anders Breivik.

'My name is death to traitors, freedom for Britain.' This was the reply he gave when asked in the Westminster Magistrates Court to confirm his name (qtd in Booth et al. 2016). Mair had a long history of mental health problems. During the case procedure, it became evident that he had been influenced by much of the rhetoric upheld by the nationalist right in the Brexit campaign. Witnesses before the court testified that during the attack he had cried out 'this is for Britain', 'keep Britain independent', and 'Put Britain first' (qtd in Cobain and Taylor 2016).

The judge on the case said there was no doubt that Mair had murdered Jo Cox 'for the purpose of advancing a political, racial and ideological cause, namely that of violent white supremacism and exclusive nationalism most associated with Nazism and its modern forms'. ${ }^{12}$

Although the politicians and activists campaigning for Brexit at the time cannot, of course, be held directly responsible for this horrendous act of a madman, it is still equally impossible to completely escape the fact that political messages are sometimes received in different ways than they are intended to be interpreted. As Alex Massie (2016) wrote in The Spectator: 'When you shout BREAKING POINT over and over again you don't get to be surprised when someone breaks.' Massie argued that when politics are presented as a matter of life and death as in the Brexit campaign-as a question of national survival-'don't be surprised if someone takes your word for it'.

As the debate leading up to the exit progressed some would go even further. One such person was Alan Craig, former leader of the Christian Peoples Party. Speaking at the UKIP annual conference in 2018 he said that Muslim sex gangs had for decades abused and raped white English girls, to the extent that it had become a 'holocaust of our children' (qtd in Bloom 2018).

\section{Political Predicament}

Despite Michaels Gove's insistence that Britain would after the vote hold all the cards in the coming negotiations with the EU, it still proved to be difficult to finalize a beneficial exit agreement. Several contradictions in 
the UK's position did not help, for example keeping frictionless commerce with Europe while breaking out of the Single Market and striking independent trade deals around the world. Britain soon plunged into political predicaments and there were also increased reports of clashes in the streets between native Brits and foreigners (Schindler 2017). It seems that as Brexit was largely seen as a vote against immigration, some of those that had been accused of racism during the campaign felt vindicated by the results.

The spread of conspiratorial fake news about the EU was also increasing alongside prolonged difficulties in finding a viable path for Brexit. On social media many people were falsely quoting the Lisbon Treaty, claiming that by 2020 Britain would lose its veto on fishing and agriculture, and that by 2022 it would be forced to adopt the Euro (Toynbee 2019). Ultimately this was a misinformation campaign saying that if Britain could not get out in time it would be trapped as a subjugated state within a European federation. One story said that Britain would lose control of its borders to the Schengen scheme, and that it would have to hand the military over to Brussels. Another insisted that the London Stock Exchange would be moved to Frankfurt (ibid.)

In the wake of the Brexit vote, the previously stable UK party system was being tested. Political dividing lines in the UK were no longer primarily defined by the Left/Right divide, but rather by a new Remain/Leave division, which was threatening to rip the British socio-political fabric apart. In the 2019 EU Parliament election, the Brexit Party came out on top and became the largest UK party in the EU Parliament.

Under Johnson, the Conservative Party responded to this threat by more or less adopting the approach of the UKIP/Brexit Party on the Brexit process. This is similar to moves made by Mark Rutte in the Netherlands, and that of the Social Democrats in Denmark when adopting the policy of the Danish Peoples Party on immigration.

When the exit negotiations had broken down and Johnson was embarking on his first visit as Prime Minister to EU capitals, he blamed rebels within his Conservative Party for the EU's harsh stance in the negotiations, saying they were undermining his negotiating strategy. Measuring this on the populist rhetorical stencil, discussed before, we see here how the EU was positioned as the external enemy and rebel Conservatives as the internal traitors.

After Johnson finally struck a new exit deal, amending the one that had been negotiated by then Prime Minister Theresa May, he was refused 
ratification in the House of Commons, and the UK once again headed for a general election in December 2019. By his firm stance on Brexit, Johnson was able to hold the Brexit Party at bay and won with a huge majority, paving the way for the UK to leave the European Union.

\section{In Trump We Trust}

Populism was also taking a Neo-Nationalist turn in America in this period, culminating in the election of the flamboyant real-estate tycoon and reality TV star, Donald Trump, to the Oval Office in 2016.

Similar to what had occurred in the Brexit referendum, and in many other recent elections around the Western world and beyond, the US presidential campaign proved to be highly populist and conspiratorial. Many studies have documented the turn of Donald Trump and his supporters to populism and conspiratorialism. Content analysis of his speeches and other communications indicate that Trump was more than any other candidate prone to apply rhetoric that was 'distinctive in its simplicity, anti-elitism and collectivism'. Eric Oliver and Wendy Rahn (2016) found that Trump supporters were 'distinctive in their high level of conspiratorial thinking, nativism and economic insecurity'.

Illustrative for the more general move of the US Republican Party towards right-wing populism was for example when both Nigel Farage, and Marion Maréchal-Le Pen of the French National Rally, were in 2018 invited to address a high-level conservative and Republican gathering near Washington DC, where both US President Donald Trump and VicePresident Mike Pence were also among the speakers.

In line with the turn to nationalism and populist operations, Trump's then senior political advisor, Steve Bannon, set out three main priorities in the early days of the administration in 2017. The first marked the turn to nationalism, with primary emphasis on enhancing security and sovereignty, and the second on rebuilding America to greatness on the platform of economic nationalism. The third priority was of a populist nature, bringing about the deconstruction of the administrative state (Goldberg 2018). This last part speaks to the Deep State conspiracy theory upheld by Donald Trump and his crew, insisting that a covert vast complex of bureaucrats was ruling the country behind the scenes and without mandate from voters or elected officials. In his election campaign, Trump famously vowed to 'drain the swamp'. 
With his rhetoric, Trump appealed to the white working class that had felt betrayed by the established elite. Many in the so-called Rustbelt, such as in the states of Michigan, Wisconsin, Ohio and Pennsylvania, had felt their dignity being removed by way of the fast-moving global economy. Trump's success was gained by tapping into the frustrations that many traditional Democrat Party voters felt about their out-of-touch political elite. His supporters would not necessarily believe that Trump could reverse the situation or make their lives much better. But as they had become increasingly dissatisfied with their societal situation, many of them proved to be happy to support someone who was prepared to stick a spanner in the works of the Washington machine.

Adam Enders and Joe Uscinski (2019) maintain that the main factor explaining the support for Trump is not necessarily partisanship or even, as such, anti-elitism, sexism, nationalism or xenophobia. But rather, that his supporters were primarily those who felt their status in society being threatened, irrespective of whether their lives were being disturbed by women, minorities or by political correctness. All of the above had to be taken into account. They thus offer a host of factors that have caused grievances for many people of the working-class whites, often over a prolonged period.

Trump ran on two main slogans, both relating to the notion of America's fatigue under the liberal elite: 'Let's Make America Great Again', and 'America First'. Both are in line with long-standing ideas of American exceptionalism. As I mentioned in previous chapters, both also echoed the rhetoric of previous eras. Ronald Reagan had run on the platform of 'Making America Great Again'. And the public face of the 'America First' movement in the 1930s was Charles Lindbergh, aviation hero and Nazi sympathizer.

Trump's nationalism was geared away from multilateral treaties and alliances. In many ways it was aimed against the very international institutional architecture that the United States had led in constructing in the post-war era, discussed in a previous chapter. Instead, Trump held a Hobbesian view of the world, where the international arena was seen as a zero-sum game of competition and survival. In this anarchical world, the President would be able to throw the United States' muscle-power around to strike great bilateral deals, allegedly for the benefit of Americans. In a speech in Washington in 2016, Trump for example stated that 'the nationstate remains the true foundation for happiness and harmony' ${ }^{13}$ 
In line with the drive to relegate international institutions, the Trump administration demoded the diplomatic status of the European Union's Delegation in Washington from state equivalent embassy to the mission of an international organization. This attitude downgraded the USA to a diminished diplomatic role, which, for example, became evident during the Coronavirus Crisis of 2020. Trump's vast insults aimed at various world actors, and his unilateral tariffs, sanctions and boycotts, did not help in managing this global crisis.

\section{A Post-Truth President}

Compared to his predecessors - and indeed to most other prominent US politicians up until then-Donald Trump had an especially loose relationship with truth. The fact checking site, PolitiFact, found more of $\mathrm{Mr}$ Trump's statements to have been 'absolutely false' than of any other candidate in the race. ${ }^{14}$ For example, he upheld the bogus claims of diverse topics such as Obama's birthplace, vaccination, climate change and immigration.

By fuelling the previously discussed so-called Birther movement, suspecting Barack Obama of being foreign-born in Kenya, and, thus, not legitimate as US President, Trump and other conspiratorialists inserted doubts about his Americanness. Instead, Obama was cast as foreign, and un-American. In other words, this was the process of 'othering' even the sitting US President.

At a fundraising speech in March 2018, Mr Trump boasted that in a meeting with Canadian Prime Minister Justin Trudeau he had, without knowing the facts, made up information, insisting that the US ran a trade deficit with its northern neighbour (Smith 2018). In many communications he also claimed that climate change was a Chinese plot, designed to damage the US economy (Aistrope 2016).

When studying some of these statements, it seems that Mr Trump did not care much whether his words were true or not. These were not necessarily all deliberate lies, told to convince people of specific alternative versions of events or interpretation. Rather, these were just bullshit, uttered to divert and distort what was deemed to be correct and right. Mr Trump's relationship with truth is perhaps rather that of a bullshitter than a deliberate and committed liar. Thus, it can perhaps be concluded that Donald Trump was an archetypical example of a post-truth politician, discussed above.

Trump used similar tactics to demonize his opponents, splattering all kinds of negative labelling around. He would for example systematically 
brand Hillary Clinton as 'criminal' and 'crooked' and repeatedly declared that she 'has to go to jail' (qtd in Levitsky and Ziblatt 2018). In his crowded rallies he welcomed a frequent chant from his supporters: 'Lock her up.' During these rallies he would sometimes flirt with violent tendencies and often applauded when critics were forcefully removed from the audience. Some of the footages brought memories of militias that fascist parties of past eras often used.

After the 2018 House of Representatives elections, Trump ran into a series of clashes with a group of Democrat Party congress women of colour. He referred to them as 'hate-filled extremists' and, although most of them were US born, suggested that if they didn't like America they should go back to their countries of origin: 'They're always telling us how to run it, how to do this, how to do that. You know what? If they don't love it, tell 'em leave it' (qtd in McCarthy 2019). A familiar sounding chant at Trump campaign rallies was growing louder, 'send them back'.

As I mentioned in the previous chapter, Trump's populism perhaps most resembled that of Silvio Berlusconi in Italy, and perhaps also that of Andrej Babis, the Czech Republic billionaire and media tycoon who came to ride the populist surge.

\section{Enemies of the People}

Like so many other nativist populists, Donald Trump was a political novice. Although he did not establish his own party, which is extremely difficult to do in a first-past-the-post electoral system, he was able to win over the Republican Party, initially against the will of its establishment.

In many ways, Trump was an odd representative of the nationalist Christian right in America. With many sex scandals around him, he was never much celebrated for particularly strong morals. Previously he had upheld quite liberal views, such as on abortion and gay rights. Trump had never been particularly religious and even supported restricting gun ownership. By the time of his presidential bid, this had all changed, and he advocated the cohabitation of both Christianity and American nationalism. Quite smoothly, he emerged as the heir to the heritage of Reagan, Gingrich and the Tea Party.

With relative ease, Trump was then able to subdue the party apparatus under his own will and move it away from many fundamental principles relating to professionalism, decency and civil rights. To make up for his lack of political backing, Trump was shrewd in utilizing the media. In the election debates he would drum up controversies that would attract 
attention to him rather than to his opponents. Many of the mainstream media took the bait, including CNN and the New York Times, who covered Trump far more than his rival, Hillary Clinton. Although much of the reporting was critical, the exposure he gained was worth millions in free press-coverage.

It is also telling for the post-truth times we are living in, that after being accused of promoting fake news stories Donald Trump turned the allegation on its head and started systematically branding the mainstream media of being fake news outlets. He even labelled established news outlets like The New York Times and CNN as 'enemies of the American people' (qtd in Mounk 2018). Steve Coll (2017), of the New Yorker magazine, finds that Trump's definition of fake news seems simply to be 'credible reporting that he doesn't like'.

Some incidents around Donald Trump were outright bizarre. One occurred when he sought to buy Greenland. The huge and largely glaciered island is an autonomous country within the kingdom of Denmark. Initially, most took it as just a yarn, but later it emerged that Trump was serious about the purchase. When being explained that Greenland was not a property for sale, but a country belonging to the population living there, the US President in protest cancelled a long-planned state visit to Denmark. He got offended by the Danish PM's rebuff, who had stated that the request was 'absurd'-Greenland was not a territory that Denmark could sell. The American President responded by calling the Danish PM a 'nasty woman' and complained that Denmark did not pay enough for NATO's defence.

The whole conundrum stunned most Danes. Former Danish Foreign Minister, Villy Søvndal, said the decision 'confirms that Donald Trump is a narcissistic fool' (qtd in Nielsen 2019). These exchanges are unprecedented between Western allies in contemporary times and indicate that we had indeed entered completely new territory in international affairs.

Interestingly, this was not the only time Trump called a woman nasty. In fact, that was perhaps his most common insult for women he did not like. The list of women he has called nasty is long (see Jones 2019).

\section{VILIFYING MigRANTS}

Donald Trump proved to be unilateralist and isolationist in international relations. In many ways he was the archetypical Neo-Nationalist, fusing economic nationalism with cultural nativism. A major theme in his 
rhetoric, both prior to and after taking up the presidency, was in drumming up fears of migrant invasion across the US southern border. In doing so he would on several occasions flirt with the Great Replacement theory. When kicking off his campaign, he started by vilifying Mexican immigrants, linking them to rapes and the US drug problem. He retweeted a message by a white supremacist who falsely claimed that blacks were responsible for 80 per cent of murders of white people in America, and he also wrongly insisted that inner city crime was at a record high (Potok 2017).

In January 2019, I was transitting through Orlando, Florida, on my way back home from Medellin in Colombia. In Medellin I had encountered some of the many refugees that were fleeing the economic devastation of Maduro's far-left populist Chávismo regime in neighbouring Venezuela. Many of them relied on begging while others performed arts in the street in hope of few pesos. Their future seemed very uncertain. In Orlando I also met newly arrived Venezuelans. One of them was looking forward to starting work as a taxi driver. I asked him whether he expected many of his countrymen that were on the move to attempt entry into the United States. He said that he hoped not. In fact, he turned out to be a staunch Trump supporter, and was enthusiastic about building a border wall against Mexico, so as to prevent others from following him into the US. Our conversation reminded me that political patronage does not always follow the lines that we might expect. And, as is not all that uncommon among immigrants, the newly arrived Venezuelan refugee I met in Orlando feared that his own possibilities of succeeding might be diminished if many more followed. Thus, he now supported a president who had fought against people like himself coming to the country.

Another of my brief acquaintances in Orlando, a white working class American, told me that he had voted for Mr Trump because unlike most politicians, Trump did not speak at him, but to him. This is in line with the before-mentioned findings of Enders and Uscinski, that most Trump supporters were disillusioned with the eloquent and well-spoken elite. My white working-class acquaintance in Orlando then explained to me how refreshing it was to have a candidate who wasn't articulate, but instead sounded like one of the people. Precisely in this feeling is where much of Trump's appeal lies.

In vilifying migrants, Trump would interchangeably refer to Latino refugees and Muslim immigrants. Among promotors of the Great Replacement conspiracy theory was also Steve Bannon, former editor of Breitbart news and key advisor to Donald Trump. Bannon repeatedly 
referred to Raspail's (1973) before-mentioned novel, The Camp of the Saints. Like Marine Le Pen in France, Bannon saw the story as a prophecy, that Muslim refugees were now starting an invasion of Europe. Referring to Syrian refugees in October 2015, Bannon said: 'It's been almost a Camp of the Saints-type invasion' (qtd in Blumenthal and Rieger 2017).

Donald Trump often went out of his way to vilify Muslims, even though their communities in the US were relatively quiet, and-quite franklyinsignificant. He even went so far as implying that Barack Obama was the founder of the Muslim terrorist organization Isis. Although admitting that Obama might not himself have physically established the terrorist organization, he still insisted that Obama had been the most valuable actor in their formation: 'I give him the most valuable player award.' Trump moved on to also implicate his rival in the presidential election with the founding of Isis: 'I give her, too, by the way, Hillary Clinton.' When criticized for without merit implicating Obama with the notorious terrorist organization, Trump reiterated his claim: 'I don't care. He was the founder. The way he got out of Iraq was, that was the founding of Isis. Ok?'15 Indeed, this was Mr Trump's modus operandi-irrespective of the circumstances he was prone to always double down on his opponents. In line with his science denialism, his disrespect for the establishment and experts, Trump initially brushed off most warnings around the imminent Coronavirus Crisis in early 2020, calling it a 'hoax' and saying for example that the matter was 'under control' and that the virus would 'miraculously disappear' (Paz 2020). Prior to the outbreak he had undermined, and even in some cases dismantled, several institutions tasked with analysing threats like these, for instance when shutting the National Security Council's pandemic unit. He didn't seem to comprehend the calamity, claiming instead that the crisis was being overblown in media to hurt him in the upcoming elections. The failure to respond left the US unprepared, leading to a far greater crisis than occurred in countries where authorities responded earlier and in accordance to established knowledge and advice of experts.

\section{The Coronavirus Crisis}

The crisis even led to the very federal union of the USA coming under question, with increased friction between Trump and many state governors over division of power in dealing with the catastrophe. Later, Trump blamed several outsiders for the crisis, most often China where the virus 
originated, but also the European Union, and most notoriously the World Health Organization, which had criticised those countries that failed to take the Covid-19 disease seriously enough. When the virus was ripping through the US Trump responded by halting funding to WHO. He had also moved to exploit the crisis to promote some of his most contested policies, such as of building his border wall to Mexico. In contrast to the chaos that reigned in the USA, China attempted to present itself as a responsible world leader, not so subtly seeking to exploit the opportunity to advance its place in the international order, at the expense of the United States.

\section{The Muslim Connection}

Relationships between the United States and many Muslim countries have been strained for a long while. The strife is for example evident in repeated invasions of US militaries in the Middle East, and in terrorist actions of Arabs in the USA, as I discussed in the previous chapter.

The controversy around the planned Islamic community centre in lower Manhattan-Park51-is illustrative of the combative attitude. Opposition soon rose, branding the project as the 'Ground-Zero mosque'. The leading campaigner, Pamela Geller (2010), wrote that this was 'Islamic domination and expansionism. The location is no accident. Just as Al-Aqsa was built on top of the Temple in Jerusalem.'

Geller claimed to be at the frontline of a cultural war: 'To allow a mosque at a place a Muslim gang destroyed on 9/11 would amount to formally blessing Islam's 1400-year-old tradition of exclusivity and suppression of all persons of all other faiths. It would be a 100 per cent victory of Islam and Sharia law over the US Constitution and America's timehonored democracy and pluralism.'

This rhetoric gained wide political backing in the USA. Former VicePresidential candidate Sarah Palin tweeted that the community centre would be a 'a stab in the heart' of Americans. Previously discussed former speaker of Congress, Newt Gingrich, also echoed Geller, warning that the mosque was a step towards replacing the US Constitution with the totalitarian supremacy of 'Sharia law', and that the project, in effect, amounted to a case of 'cultural, political and legal jihad' (qtd in Wright 2016).

President Donald Trump struck a similar tone. He proposed that authorities would operate a database keeping track of American Muslims. When in 2016 he argued for banning many Muslims from entering the 
USA, he said: 'I think Islam hates us' (qtd in Schleifer 2016). After becoming president, he indeed found ways around hindrances to allowing citizens of several Muslim-dominated countries from travelling to the USA.

Like his aid Steve Bannon, the US President also voiced his concern regarding the Islamization of Europe, especially in the UK. In 2015, he tweeted that British authorities were disguising 'their massive Muslim problem' (qtd in Walters 2015). He maintained that more Muslims in the UK joined Isis than enlisted in the British army. He went on to claim that parts of London and Paris were 'so radicalized' that police officers were 'afraid for their very lives'. Once he retweeted three unsubstantiated antiMuslim videos posted by British far-right activist, Jayda Fransen. One of them showed a Muslim destroying a statue of the Virgin Mary, another showed a group of Muslims pushing a boy off a roof, and a third indicated that a Muslim was hitting a Dutch boy on crutches (see in Weaver and Jacobs 2017).

At a rally in Florida in 2017, Trump turned his sights on Sweden: 'You look at what's happening last night in Sweden. Sweden! Who would believe this? Sweden ... They took in large numbers. They're having problems like they never thought possible.' This was quite stunning as nothing really noteworthy had happened in Sweden that night. Possibly, the American President had been watching Fox News that had aired a dystopian view of Sweden after accepting large numbers of asylum seekers (Becker 2019).

As already established, Donald Trump has long made false claims about Muslims. For instance, he insisted that Muslims knew in advance about the San Bernardino mass shooting in December 2015 and did not report it. Famously, he accused Muslims in New Jersey of having celebrated the terrorist attacks on 9/11. In a television interview on $A B C$ News in November 2015 he told presenter George Stephanopoulos that 'thousands and thousands of people were cheering as that building was coming down' (qtd in Kessler 2015). Like so many others of his statements, his claim was not substantiated with evidence. It has been well documented that some Arabs in the Middle East did celebrate the attack, but no evidence at all existed that Arabs in New Jersey were cheering as the towers fell.

All of these statements were untrue. Perhaps it is telling for Mr Trump's overall relationship with the truth that he announced his plan of banning citizens from several Muslim-dominated countries from entering the USA on conspiratorialist Alex Jones's radio show. 
Donald Trump's rhetoric has unavoidably filtered out and impacted his aides and supporters. Illustrative of that was when his National Security Advisor, Michael Flynn, tweeted that to fear Muslims was rational. Flynn went on to describe Islam as a 'malignant cancer' (qtd in Potok 2017).

\section{White Supremacists}

Mr Trump has not only been classified as an American nationalist, but he has also been suspected of sympathizing with white supremacist movements. Although he has often surely refused to condole their actions, he has also on several occasions been hesitant in condemning some of their hateful speech. It is also telling that the racist radical-right in America sincerely celebrated Trump's election. One such person was Andrew Anglin, founder of the neo-Nazi website, Daily Stormer — named after the German Nazi propaganda gutter press known as Der Stürmer. He wrote: 'We won, brothers. All of our work. It has paid off. Our Glorious Leader has ascended to God Emperor. Make no mistake about it: we did this.' $\mathrm{He}$ went on writing: 'All my friends in Europe are texting me "NOW WE'RE GOING TO GET TO KICK OUT THESE MONKEYS!!!!”' In conclusion he wrote that 'the White race is back in the game' (qtd in Ennis 2016).

Internationally recognized white supremacist Richard Spencer insisted that Trump's election marked a victory for identity politics (Potok 2017). This is significant, as promoting identity is indeed the core to NeoNationalism, that is, the post-war populist version of nationalism analysed in this book. When Trump was elected, Spencer led a modified Nazi chant: 'hail Trump, hail our people, hail victory' (qtd in Snyder 2018).

Anti-Muslim attitudes in the US have, like in Europe, sometimes taken a violent turn. One such example occurred in Charlottesville, Virginia, in 2017. White supremacists clashed with counter demonstrators over the removal of a statue of confederate legend, General Robert E. Lee. In the early afternoon on Saturday 12 August the twenty-year-old James Alex Fields Jr of Ohio ploughed his car into a crowd of anti-racist protesters, killing a thirty-two-year-old woman and injuring at least ninteen others.

An ultra-nationalist group called Unite the Right had organized the rally, which was described in the media as one of the largest white supremacist events in recent US history (Strickland 2017). Gangs of white supremacists marched across the campus of the University of Virginia carrying torches and yelling slogans such as 'white lives matter' and 'blood and soil'. Another set of chants went'You will not replace us', followed by; 'Jews will 
not replace us'. When he was asked to condemn the violence, President Trump said that there were good people on both sides of the dispute.

Research has shown that violence by far-right actors has spiked in America since Trump emerged as a prominent political force. Historian Kathleen Belew points out that the violence of political extremists often increases when their views are more tolerated by the national political leadership. She maintains that the election of Trump to the White House has in a way worked to legitimize the use of violence among the far-right extremists groups (see in Tenold 2019). J. M. Berger furthermore states that in the Trump era, many of those formerly on the fringe saw an opening in the national discussion for their politics (ibid.). During the Coronavirus Crisis Trump was prone to pin blame on China, where the virus had originated. According to many Chinese Americans, this led to increased anti-Chinese sentiments and abuse against Chinese people throughout the United States.

\section{White Genocide}

The anti-Semitic chant is here quite interesting as Neo-Nationalists in Europe had mostly turned their sights away from Jews and firmly towards Muslims instead. Both paradigms, anti-Semitism and anti-Muslim sentiments, were, however, of the same nature, that is, in casting a specifically defined outgroup as foreign interlopers who were to be expunged. Curiously, the American far-right activists in Charlottesville were still revelling in German Nazi symbolism, such as swastikas and Hitler-quotes. Among slogans on their posters were 'Jews are Satan's children.' At the rally, American white supremacist leader David Duke said that 'the American media, and the American political system, and the American Federal Reserve, is dominated by a tiny minority: the Jewish Zionist cause' (qtd in Rosenberg 2017).

American anti-Semitism and anti-Muslim sentiments in Europe stem from similar fears nurtured by the Neo-Nationalist far-right. The two cases cast a light on an ongoing trepidation on both sides of the Atlantic, the anxiety over the dominant people being replaced by a foreign public, that is, the Great Replacement conspiracy theory of a white genocide being plotted by evil external forces, and even already underway. This is the ongoing fear that Christian identity is under siege by multiculturalism and an infiltration of people of other ethnic origins. During the Coronavirus Crisis, similar fears were rising around Chinese influence in America. 
Correspondingly, studies have found that most of Trump's supporters believed that Christian whites were being discriminated against in America (Judis 2018). Organizations of American white nationalist movements have been on the rise in recent years. Their most common discussion theme was indeed that of the White Genocide conspiracy theory. Perhaps unsurprisingly, J. M. Berger (2016) found that most white nationalists in America supported Donald Trump for President. Apart from white genocide, they referred to him more often than to any other topic in 2016. Their most tweeted video on YouTube was a documentary titled Adolf Hitler: The Greatest Story Never Told. The collection of footage insists that Hitler was not the monster that the mainstream media and elite academia portrayed him as being, but that he, in fact, was a brave fighter against the world's most evil forces, that is, Zionist bankers and economic elite (Berger 2016).

Numerous violent neo-Nazi movements have existed in the US through history, as I have briefly mentioned in former chapters. One of them was the fast emerging Atomwaffen Division (in German, meaning atomic weapon), which was gathering many separated individuals and groupings from diverse neo-Nazi online discussion boards. This movement was growing into a kind of a small-scale terror network, with several killings and other violent acts being carried out in its name, for the protection of the white Christian population in America.

\section{Pizza-Gate}

The effect of far-right populism and sinister misinformation tactics for political gains have come in many and often unforeseen forms. The story of Pizza Gate is telling for this turn. In March 2016, the social media newsfeeds of many Americans were suddenly filled with stories indicating that Hillary Clinton and other Democrats were secretly running a paedophile ring out of a pizza parlour in Washington, DC. The gobsmacking revelations were tagged Pizza-Gate. The reporting told of leaked emails from Clinton's campaign chairman, John Podesta, unravelling coded message about human trafficking and the paedophile operation exploiting defenceless children. By the November presidential elections more than one million tweets had been sent with the hashtag \#pizzagate (Douglas et al. 2017). The story was spread by the infamous American conspiracy site InfoWar, published by Alex Jones.

Among those following the story was one Edgar Welch from North Carolina. On 4 December 2016 Welch travelled to DC on a mission to 
break up the paedophile kidnapping ring that he had read about online. Upon arriving in the US capital, he stormed with his raised assault rifle into the Comet Ping Pong Pizza parlour to rescue the abused children he thought were being kept there.

After quite a commotion and a few shots fired, Welch was finally faced with the fact that no children were being kept there. It was just a pizza joint. Only after the incident did Welch come to realize that the data he obtained online about the alleged evil operation was inaccurate. He explained to an interviewer that 'the intel on this wasn't 100 percent' (qtd in Hannon and Hannon 2016). In 2017, Welch was sentenced to four years in prison. He, the people in the pizza parlour, Hillary Clinton, and indeed US voters, all fell victim to a fabricated conspiracy theory spread as news online.

Many similar violent events have followed. In October 2018, eleven people were killed in a Pittsburgh synagogue by anti-Semite shooter. In August 2019, another anti-immigrant and far-right shooter opened fire on primarily Latinos in the border city of El Paso, killing twenty-two people and injuring twenty-four others.

\section{The National Rally}

One of the effects of nativist populism in the third wave was of undermining traditional politics and in vilifying the establishment. This led to the demise of many rooted political parties and indeed to the breakup of the party system in many countries. This was for instance the case in France. Although nativist populists had failed in finding power in France, they were successful in undermining the traditional parties, both to the left and right. In 2017, the remarkable happened and neither of the two major parties graduated to the second round of the presidential election. Socialist Party leader, François Holland, had fallen so unpopular that he didn't even stand. Two relative political novices ended up competing for the presidency. And even though Emmanuel Macron easily won the race for the Élysée Palace on a fully liberal democratic ticket, Marine Le Pen, leader of the National Rally (formerly the National Front) did remarkably well, grabbing just over one-third of the vote.

It is noteworthy here that Macrons success came on an anti-populist premise. But similar to the populists he was opposing, he himself was also fighting against the establishment. His politics were thus in many ways defined by populism, as his success indeed came by opposing both the populists and the political establishment. 
Marine Le Pen's father, Jean Marie, discussed in previous chapters, had always been a marginal, discredited and polarizing figure in French politics, nicknamed the Devil of the Republic. Marine had however systematically set out to de-demonize the party, and in 2015 she expelled her own father-the party's founder-for flirting with Nazism.

Jean-Marie Le Pen had also suggested that the Ebola outbreak in Africa could be a solution to its population explosion. When addressing supporters, the eighty-five-year old political veteran leader said: 'In our country and in all Europe, we have known a cataclysmic phenomenon-a migratory invasion that, my friends, we are seeing only the beginning of today' (qtd in Willsher 2014). With the old guard out, the rebranded party, National Rally, had by the 2017 presidential election come in from the cold and to a position of new prominence in French politics.

\section{No Frexit}

On Europe, the National Rally had changed tactics and refrained from campaigning for a so-called Frexit-a French exit from the European Union. Instead, Marine Le Pen emphasized rolling back the integration process, saying that with the electoral victories of populist leaders like Italy's Matteo Salvini and Hungary's Viktor Orbán the tide had turned in favour of nationalists who could reform the EU from within.

The result of the Brexit referendum in 2016 did not reinvigorate antiEU forces in other countries. Prior to the vote, Geert Wilders had been highly successful in rallying support for Nexit-exit of the Netherlands from the EU. In Denmark similar voices had also been prominent. However-contrary to what many expected-exit movements in other EU member states instead lost momentum after the Brexit vote, at least in the short term.

During the French 2017 elections debate, misinformation tactics that had for example been used by Russian actors to interfere in the Brexit campaign, and in the US Presidential elections in 2016, were put to use once again, now for the benefit of Marine Le Pen against Emmanuel Macron (Snyder 2018).

The Syrian Refugee Crisis had also elevated support for Marine Le Pen. Although she had made many efforts to normalize the party and making it more acceptable in society, at the height of the crisis she still set out to block all new migrants from entering France. Indeed, she rather sought to see the back of many existing immigrants out of the country. 
In March 2015, Marine Le Pen catered to the Great Replacement theory when writing on Twitter that France was under migratory submersion. She then invited her followers to read Jean Raspail's novel, The Camp of the Saints. As I have already discussed, Raspail's book illustrates the demise of Western civilization through mass immigration from India. Biological race is here a key factor in explaining the fates of societies. Previously, Marine Le Pen had said that the book painted a picture of a Europe being invaded by hordes of 'stinking' dark-skinned migrants and 'rat people' flowing in a 'river of sperm' (qtd in Symons 2017).

This idea of the submersion of the French culture to Islam has also been illustrated in prominent contemporary literature, most famously in Michel Houllebecq's (2016) novel Submission. In a non-fiction bestseller titled The French Suicide, Eric Zemmour (2014) argued that for forty years France had been gradually moving towards becoming an Islamic country.

\section{A Run on Rome}

As I have illustrated in previous chapters, populist politics have a longstanding history in Italy. In the third wave, the double blow of first the Euro Crisis and then mass migration from north Africa served to elevate several actors that upheld nationalist and populist views.

After the April elections of 2008, Silvio Berlusconi was back in the Prime Minister's office. The Euro Crisis was about to bite, and he was blamed for the poor state of Italy, for instance of not managing the country's staggering foreign dept. In 2011 he was ousted and two years later he was sentenced for tax fraud. Berlusconi turned increasingly Eurosceptic, for example blaming his demise on Angela Merkel, Nicolas Sarkozy and Christine Lagarde - as well as blaming global economic powers in general.

The Five Star Movement founded by comedian Beppe Grillo was also rising to new heights in the third wave. Grillo was an interesting blend of a social-liberal anarchist who upheld a rather leftist socio-economic policy. He advocated for direct democracy and free access to an open Internet. His populism was mostly found in his profound discontent for the establishment, including also the European Union. In many ways, the Icelandic Pirate Party resembles the Five Star Movement. In an interview Grillo described politicians as 'parasites', and said, 'We should send them all home!' (qtd in Bartlett 2018). 
At the same time, Matteo Salvini was rebranding the neo-racist Northern League as The League (Lega). Similar to Donald Trump in America, Salvini ran on the slogan 'Italians First'. The League was much more clearly far-right nationalist than the Five Star Movement.

The 2018 election brought a coalition of the Five Star Movement and Lega to power in Rome. Like in France, the traditional party system in Italy had collapsed from under populist parties piling on, who were able to push the established parties aside. The supporters of these parties were found to be much more sympathetic to Italy's fascist past than people of previous generations had been (Judis 2018). In 2019, Salvini dissolved the government in an attempt to increase his influence in government even further. That attempt backfired when his collaborators in the Five Star Movement instead formed a government with the mainstream Democratic Party.

By the time of the Coronavirus Crisis Italy had for extended periods over the last three decades been governed by several creeds of populists. As populists in power often tend to undermine professionalism in governance, it can thus be argued that Italy was left less prepared to deal with the serious crisis when it hit in early 2020.

\section{Notes}

1. Al Jazeera. 2019, 16 March. 'New Zealand mosque attacks suspect praised Trump in manifesto'.

2. Pew Research Centre. 2017. 'Europe's Growing Muslim Population'.

3. Vidkun Quisling, leader of the Norwegian interwar nationalist party, National Samling, was a Nazi collaborator and traitor during the German occupation of Norway in WWII. He was executed by firing squad in 1945.

4. The Local, 29 August 2017. 'Meeting between Swedish and Norwegian ministers scrapped following "no-go zone" claims'.

5. See Yle Uutiset. 2008. 'Police to Investigate Helsinki City Council Member's Blog'.

6. See mtv.fi. 2010. 'Islamin yhdistäminen pedofiliaan toi Halla-aholle sakot myös hovilta'.

7. 'Sverigedemokraternas principprogram'. 2003.

8. See the Hungarian Prime Ministry official site on Ministerelnok.hu. 2018, 8 February. 'Prime Minister Viktor Orbán's speech at the annual general meeting of the Association of Cities with County Rights'.

9. Dw.com. 2018. 'Poland, Hungary say EU migration policy has failed'.

10. See on euvsdisinfo.eu.

11. Posted on hidfo.ru in 2017.

12. BBC News. 2016, November. 'Jo Cox murder: Judge's sentencing remarks to Thomas Mair'. 
13. The New York Times. 2016, 28 April 2016. 'Transcript 2016: Donald Trump's Foreign Policy Speech.'

14. The Economist. 2016, 10 September. 'Art of the lie'.

15. The Economist. 2016, 10 September. 'Yes, I'd lie to you'.

\section{REFERENCES}

Aistrope, T. (2016). Conspiracy Theory and American Foreign Policy (1st ed.). Manchester: Manchester University Press.

Åkesson, J. (2009). Muslimerna Är Vårt Största Utländska Hot. Stockholm: Aftonbladet.

Art of the Lie. (2016). The Economist.

Barfield, T. (2015). How German Media Shaped the Greece Crisis. Thelocal.de.

Bartlett, J. (2018). Italy's Five Star Movement and the Triumph of Digital Populism. Coffee House. Retrieved from Blogs.spectator.co.uk.

Bawer, B. (2012). The New Quislings: How the International Left Used the Oslo Massacre to Silence Debate About Islam. Broadside e-books.

Becker, J. (2019). The Global Machine Behind the Rise of Far-Right Nationalism. The New York Times.

Becker, S., Fetzer, T., \& Novy, D. (2017). Who Voted for Brexit? A Comprehensive District-Level Analysis. Economic Policy, 32(92), 601-650.

Bennett, O. (2016). The Brexit Club: The Inside Story of the Leave Campaign's Shock Victory. London: Biteback Publishing.

Berger, J. M. (2016). Nazis vs. ISIS on Twitter: A Comparative Study of White Nationalist and ISIS Online Social Media Networks. Program on Extremism Report: George Washington University.

Bergmann, E. (2014a). Iceland: A Postimperial Sovereignty Project. Cooperation and Conflict, 49(1), 33-54. https://doi.org/10.1177/0010836713514152.

Bergmann, E. (2014b). Iceland and the International Financial Crisis: Boom, Bust and Recovery. Basingstoke and New York: Palgrave Macmillan.

Bergmann, E. (2016). The Icesave Dispute: A Case Study into the Crisis of Diplomacy during the Credit Crunch. Nordicum-Mediterraneum, 12(1).

Bergmann, E. (2017). Nordic Nationalism and Right-Wing Populist Politics: Imperial Relationships and National Sentiments. London and New York: Palgrave Macmillan.

Bloom, D. (2018). UKIP Speaker Branded 'Disgraceful' after Calling Asian Grooming Gangs a 'Holocaust of Our Daughters'. London: Mirror Online.

Blumenthal, P., \& Rieger, J. M. (2017). This Stunningly Racist French Novel Is How Steve Bannon Explains the World. HuffPost.

Booth, M. (2014). The Almost Nearly Perfect People: The Truth about the Nordic Miracle. London: Jonathan Cape. 
Booth, R., Dodd, V., Rawlinson, K., \& Slawson, N. (2016). Jo Cox Murder Suspect Tells Court His Name Is 'Death to Traitors, Freedom for Britain'. The Guardian.

Boréus, K. (2010). Including or Excluding Immigrants? The Impact of RightWing Populism in Denmark and Sweden. Diversity, Inclusion and Citizenship in Scandinavia, 127-158.

Boyer, P. (1995). When Time Shall Be No More: Prophecy Belief in Modern American Culture (1st ed.). Harvard University Press.

Byford, J. (2011). Conspiracy Theories: A Critical Introduction. Springer.

Chrisafis, A., Connolly, K., \& Giuffrida, A. (2019). The New Populism: How the Far-Right Appeals to Women Voters. The Guardian.

Cobain, I., \& Taylor, M. (2016). Far-Right Terrorist Thomas Mair Jailed for Life for Jo Cox Murder. The Guardian.

Cobain, I., Parveen, N., \& Taylor, M. (2016). The Slow-Burning Hatred That Led Thomas Mair to Murder Jo Cox. The Guardian.

Coll, S. (2017). Donald Trump's 'Fake News' Tactics. The New Yorker.

Davey, J., \& Ebner, J. (2019). 'The Great Replacement': The Violent Consequences of Mainstreamed Extremism. ISD Think Tank.

Douglas, K., Sutton, R., \& Cichocka, A. (2017). The Psychology of Conspiracy Theories. Current Directions in Psychological Science. Retrieved from Kar. kent.ac.uk.

Drabik, J. (2017). The Dark Modern Age: A Farewell to the Enlightenment. Gold Book.

Dunne, D. (2014). Finns Party MP Remains Defiant after Race Hate Conviction. Helsinki Times.

Duyvendak, J. W., \& Kesic, J. (2018). The Rise of Nativism in Europe. EuropeNow.

Elabdi, F. (2019). Dane Who Wants to Deport Muslims, Ban Islam to Run in Election. Aljazeera.

Elgenius, G., \& Rydgren, J. (2019). Frames of Nostalgia and Belonging: The Resurgence of Ethno-Nationalism in Sweden. European Societies, 21(4), 583-602.

Enders, A. M., \& Uscinski, J. E. (2019). On Modeling Support for Donald Trump. Joe Uscinski's Website.

Ennis, D. (2016). Who's Happy Trump Won? The Klan, Nazis and Anti-Immigrant Activists Worldwide. LGBTQ Nation.

Espersen, S. (2015). DF Om Krigen Mod IS: Vi Bliver Nødt Til at Bombe Civile $\mathrm{Nu}$ - Også Kvinder Og Børn. Copenhagen. Retrieved from http://politik.tv2.dk.

Europe's Growing Muslim Population. (2017, December 6). Pew Research Center's Religion \& Public Life Project. Retrieved from http://www. pewforum.org.

Fekete, E. (2018). Europe's Fault Lines: Racism and the Rise of the Right. London: Verso Books. 
Fredricks, B. (2020, 13.4). 'Roger Stone: Bill Gates may have Created Coronavirus to Microchip People'. New York Post.

Gad, U. P. (2010). (How) Can They Become like Us?: Danish Identity Politics and the Conflicts of'Muslim Relations'. Museum Tusculanum. Retrieved from Curis.ku.dk.

Geller, P. (2010). The 9/11 Imam. Atlas Shrugs. Retrieved from pamelageller.com. Goldberg, J. (2018). Suicide of the West: How the Rebirth of Tribalism, Populism, Nationalism, and Identity Politics Is Destroying American Democracy. Crown Publishing Group.

Graham-Harrison, E., \& Rasmussen, J. E. (2018). Stigmatised, Marginalised: Life inside Denmark's Official Ghettos. The Observer.

Hannon, E., \& Hannon, E. (2016). Comet Pizzeria Gunman Says 'the Intel on This Wasn't 100 Percent' in First Interview. Slate.

Harrison, S. (2018). The Weight of Negativity: The Impact of Immigration Perceptions on the Brexit Vote. In Trumping the Mainstream (pp. 185-203). Routledge.

Hellstrom, A. (2016). Trust Us: Reproducing the Nation and the Scandinavian Nationalist Populist Parties. Oxford: Berghahn Books.

Henley, J., Roberts, D., Henley, J., \& Roberts, D. (2018). 11 Brexit Promises the Government Quietly Dropped. The Guardian.

Houellebecq, M. (2016). Submission (Trans. ed.). New York: Picador.

Islamin Yhdistäminen Pedofiliaan Toi Halla-Aholle Sakot Myös Hovilta. (2010). Mtv.fi.

Ivarsflaten, E. (2006). Reputational Shields: Why Most Anti-Immigrant Parties Failed in Western Europe, 1980-2005. Annual Meeting of the American Political Science Association, Philadelphia.

Jo Cox Murder: Judge's Sentencing Remarks to Thomas Mair. (2016). BBC News.

Jones, J. (2019). Here's A Running List Of The Women Trump Has Demeaned Using The Word 'Nasty'. HuffPost.

Judis, J. B. (2018). The Nationalist Revival: Trade, Immigration, and the Revolt Against Globalization. New York, NY: Columbia Global Reports.

Jupskås, A. R. (2015). The Persistence of Populism. The Norwegian Progress Party 1973-2009. University of Oslo.

Jupskås, A. R., Ivarsflaten, E., Karlsnes, B., \& Aalberg, T. (2016). Norway: Populism from Anti Tax Movement to Government Party. Unpublished Working Paper.

Kallestrand, G., Hahne, W., Andersson, P., \& Ohlson, J. (2015). Finland, You Do Not Want the Swedish Nightmare.

Kessler, G. (2015). Trump's Outrageous Claim That 'Thousands' of New Jersey Muslims Celebrated the 9/11 Attacks. Washington Post.

Klages, E. P. (2019). Who Votes for Germany's Far-Right Party AfD? Not Who You'd Think. Dw.com. 
Klein, A. (2013). The End of Solidarity? On the Development of Right-Wing Populist Parties in Denmark and Sweden. In Exposing the Demagogues: RightWing and National Populist Parties in Europe. Berlin: Konrad Adenauer Stiftung.

Krasodomski-Jones, A. (2019). Suspicious Minds: Conspiracy Theories in the Age of Populism. Brussels: Martens Centre.

Lacarpia, K. (2016). 'Offended Muslims’ Attack Christmas Tree? Snopes.

Levitsky, S., \& Ziblatt, D. (2018). How Democracies Die. New York: Crown.

Lewis, P. (2018). Steve Bannon: I Want to Drive a Stake through the Brussels Vampire. The Guardian.

Lister, S. (2016). Vote Leave Faces Criticism over Turkey 'Criminals' Claim. The Independent.

Machiavelli, N. (1550). The Prince.

Mahony, H. (2014). Orban Wants to Build 'Illiberal State'. EUobserver.

Massie, A. (2016). A Day of Infamy. The Spectator.

McCarthy, T. (2019). Trump Rally Crowd Chants 'Send Her Back' after President Attacks Ilhan Omar. The Guardian.

Meeting between Swedish and Norwegian Ministers Scrapped Following 'No-Go Zone' Claims. (2017). Thelocal.no.

Milne, R. (2017). Norway Minister Sparks War of Words with Sweden over Immigration. Financial Times.

Moffitt, B. (2017). Liberal Illiberalism? The Reshaping of the Contemporary Populist Radical Right in Northern Europe. Politics and Governance, $5(4), 112-122$.

Mounk, Y. (2018). The People Vs. Democracy: Why Our Freedom Is in Danger and How to Save It. Harvard University Press.

Mudde, C. (2004). The Populist Zeitgeist. Government and Opposition, $39(4), 542-563$.

New Zealand Mosque Attacks Suspect Praised Trump in Manifesto. (2019). Aljazeera.

Nielsen, J. B. (2019). Villy Søvndal: "Det bekræfter, at Donald Trump er en narcissistisk nar". Berlingske.dk.

Nordensvard, J., \& Ketola, M. (2015). Nationalist Reframing of the Finnish and Swedish Welfare States-The Nexus of Nationalism and Social Policy in FarRight Populist Parties. Social Policy \& Administration, 49(3), 356-375.

Norocel, C. (2017). Finland: From Agrarian to Right-Wing Populism. In Populist Political Communication in Europe. Routledge.

Nougayrede, N. (2015). The Conspiracy Theories of Extreme Right and Far Left Threaten Democracy. The Guardian.

Oliver, J. E., \& Rahn, W. M. (2016). Rise of the Trumpenvolk: Populism in the 2016 Election. The ANNALS of the American Academy of Political and Social Science, 667(1), 189-206.

Osborne, S. (2019). Polish Newspaper Runs Front Page List on 'How to Spot a Jew'. The Independent. 
Palma, B. (2017). Are Police in Sweden No Longer Investigating Rapes Since Migrants Arrived? Snopes.

Paz, C. (2020). All the President's Lies About the Coronavirus. Politico.com.

Persson, E. (2015). Banning 'Homosexual Propaganda': Belonging and Visibility in Contemporary Russian Media. Sexuality es Culture, 19(2), 256-274.

Poland, Hungary Say EU Migration Policy Has Failed. (2018). Dw.com.

Police to Investigate Helsinki City Council Member's Blog. (2008). Yle Uutiset.

Pomerantsev, P. (2015). Nothing Is True and Everything Is Possible: The Surreal Heart of the New Russia. New York: PublicAffairs.

Porter, T. (2017). How the 'Deep State' Conspiracy Theory Went Mainstream. Newsweek.

Potok, M. (2017). The Year in Hate and Extremism. Southern Poverty Law Center. Potok, M., \& Terry, D. (2015). 10 Right-Wing Conspiracy Theories That Have Slowly Invaded American Politics. Salon.

Prime Minister Viktor Orbán's Speech at the Annual General Meeting of the Association of Cities with County Rights. (2018). Miniszterelnok.hu.

Pyykkönen, M. (2011). 'Luonnollinen Suomalaisuus' Ja Etnosentrismi Kahdeksan Suurimman Puolueen Eduskuntavaaliohjelmissa 2011. Politiikka: Valtiotieteellisen yhdistyksen julkaisu, 53(2).

Rankin, J., \& Waterson, J. (2019). How Boris Johnson's Brussels-Bashing Stories Shaped British Politics. The Guardian.

Raspail, J. (1973). Le Camp des Saints. Paris: Robert Laffont.

Raunio, T. (2013). The Finns: Filling a Cap in the Party System. In Expoising the Demagogues: Right-Wing and National Populist Parties in Europe. Berlin: Konrad Adenauer Stiftung.

Rosenberg, Y. (2017). 'Jews Will Not Replace Us': Why White Supremacists Go after Jews. Washington Post.

Ross, T. (2016). Boris Johnson: The EU Wants a Superstate, Just as Hitler Did. The Telegraph.

Rydgren, J. (2002). Radical Right Populism in Sweden: Still a Failiure. Scandinavian Political Studies, 25(1), 27-56.

Rydgren, J. (2010). Radical Right-Wing Populism in Denmark and Sweden: Explaining Party System Change and Stability. SAIS Review of International Affairs, 30(1), 57-71.

Sxland, I. (2016). Facebook Post. Inga Saland.

Schaeffer, K. (2020). Nearly three-in-ten Americans Believe COVID-19 was made in a Lab. Pew Research Centre.

Schindler, J. (2017). Not So Great: Britain Grows Increasingly Hostile to EU Citizens. Spiegel Online.

Schleifer, T. (2016). Donald Trump: 'I Think Islam Hates Us'. CNN.

Scott, M. (2019). Half of European Voters May Have Viewed Russian-Backed 'Fake News'. Politico. 
Seierstad, A. (2015). One of Us: The Story of Anders Breivik and the Massacre in Norway. New York: Farrar, Straus and Giroux.

Serwer, A. (2011). Debunking Sharia Panic, ACLU Edition. The American Prospect.

Shields, M. (2019). Austrian Far-Right Leader Urges Fight against 'Population Exchange'. Reuters.

Simonnes, K. (2011). I Stjalne Kler?: En Analyse Av Endringer $i$ Hoyres, Arbeiderpartiets $O g$ Fremskrittspartiets Innvandrings-Og Integreringspolitikk Fra 1985 Til 2009. University of Oslo.

Skarvoy, L. J., \& Svendsen, S. H. (2011). Dansk Partileder Refser Siv Jensen: Hun Mangler Ryggrad. Oslo: VG.

Smith, D. (2018). Donald Trump Admits Making up 'Facts' in Trade Meeting with Justin Trudeau. The Guardian.

Snyder, T. (2018). The Road to Unfreedom. London: Penguin.

Stone, J. (2016). Hitler's Nazis Designed the EU, Ukip MEP Claims. The Independent.

Strickland, P. (2017). Unite the Right: White Supremacists Rally in Virginia. Aljazeera.com.

Sverigedemokraternas Principprogram. (2003).

Symons, E.-K. (2017). Steve Bannon Loves France. Politico.

Tenold, V. (2019). The Neo-Nazi Plot against America Is Much Bigger than We Realize. The Guardian.

Toynbee, P. (2019). The Anti-EU Lies Are Back to Exploit Britain's Weak Spot Again | Polly Toynbee. The Guardian.

Transcript: Donald Trump's Foreign Policy Speech. (2016). The New York Times.

Walters, J. (2015). Trump Ignores UK Critics and Claims Country Has 'a Massive Muslim Problem'. The Guardian.

Waterson, J. (2019). Most UK News Coverage of Muslims Is Negative, Major Study Finds. The Guardian.

Weaver, M., \& Jacobs, B. (2017). Trump Retweets British Far-Right Leader's Anti-Muslim Videos. The Guardian.

Wheen, F. (2005). How Mumbo-Jumbo Conquered the World. Publicaffairsbooks.com.

Widfeldt, A. (2015). Extreme Right Parties in Scandinavia. New York: Routledge.

Wilders, G. (2017). Our Population Is Being Replaced. No More. @geertwilderspvv. Twitter.com.

Willsher, K. (2014). Jean-Marie Le Pen Suggests Ebola as Solution to Global Population Explosion. The Guardian.

Wilson, J. (2019). Australians Are Asking How Did We Get Here? Well, Islamophobia Is Practically Enshrined as Public Policy. The Guardian.

Winneker, C. (2015). Finnish Politician Declares War on 'Multiculturalism'. Politico.

Wodak, R. (2015). The Politics of Fear: What Right-Wing Populist Discourses Mean. New York: Sage. 
Wren, K. (2001). Cultural Rajcism: Something Rotten in the State of Denmark? Social \& Cultural Geography, 2(2), 141-162.

Wright, S. (2016). Reproducing Fear: Islamophobia in the United States. In D. Pratt \& R. Woodlock (Eds.), Fear of Muslims? International Perspectives on Islamophobia (Boundaries of Religious Freedom: Regulating Religion in Diverse Societies) (pp. 45-65). Cham: Springer International Publishing.

Yablokov, I. (2014). Pussy Riot as Agent Provocateur: Conspiracy Theories and the Media Construction of Nation in Putin's Russia. Nationalities Papers 42(4). https://doi.org/10.1080/00905992.2014.923390.

Yablokov, I. (2018). Fortress Russia: Conspiracy Theories in the Post-Soviet World. Cambridge: Polity Press.

Yes, I'd Lie to You. (2016). Economist.

Zemmour, E. (2014). Le suicide francais - Ces quarante annees qui ont defait la France (A. Michel, Ed.). Paris: French and European Publications Inc.

Zúquete, J. P. (2018). The Identitarians: The Movement against Globalism and Islam in Europe. Notre Dame: University of Notre Dame Press. 